\title{
Onderzoekt alles.... : over theorie en onderzoek van accountantscontrole
}

Citation for published version (APA):

Schilder, A. (1989). Onderzoekt alles.... : over theorie en onderzoek van accountantscontrole. WoltersNoordhoff. https://doi.org/10.26481/spe.19890901as

Document status and date:

Published: 01/09/1989

DOI:

10.26481/spe.19890901as

Document Version:

Publisher's PDF, also known as Version of record

\section{Please check the document version of this publication:}

- A submitted manuscript is the version of the article upon submission and before peer-review. There can be important differences between the submitted version and the official published version of record.

People interested in the research are advised to contact the author for the final version of the publication, or visit the DOI to the publisher's website.

- The final author version and the galley proof are versions of the publication after peer review.

- The final published version features the final layout of the paper including the volume, issue and page numbers.

Link to publication

\footnotetext{
General rights rights.

- You may freely distribute the URL identifying the publication in the public portal. please follow below link for the End User Agreement:

www.umlib.nl/taverne-license

Take down policy

If you believe that this document breaches copyright please contact us at:

repository@maastrichtuniversity.nl

providing details and we will investigate your claim.
}

Copyright and moral rights for the publications made accessible in the public portal are retained by the authors and/or other copyright owners and it is a condition of accessing publications that users recognise and abide by the legal requirements associated with these

- Users may download and print one copy of any publication from the public portal for the purpose of private study or research.

- You may not further distribute the material or use it for any profit-making activity or commercial gain

If the publication is distributed under the terms of Article $25 \mathrm{fa}$ of the Dutch Copyright Act, indicated by the "Taverne" license above, 
ONDERZOEKT ALLES... 

Over theorie en onderzoek van accountantscontrole

\section{REDE}

in verkorte vorm uitgesproken bij de aanvaarding van het ambt van hoogleraar in de Bedrijfseconomie aan de Rijksuniversiteit Limburg

\section{op vrijdag 1 september 1989}

door

Drs. A. Schillder RA 
1989 Wolters-Noordhoff bv Groningen, The Netherlands

Copyright (C)A. Schilder

Alle rechten voorbehouden. Niets uit deze uitgave mag worden verveelvoudigd, opgeslagen in een geautomatiseerd gegevensbestand, of openbaar gemaakt, in enige vorm of op enige wijze, hetzij electronisch, mechanisch, door fotocopieën, opnamen, of op enige andere manier, zonder voorafgaande schriftelijke toestemming van de uitgever.

All rights reserved. No part of this publication may be reproduced, stored in a retrieval system, or transmitted, in any form or by any means, electronic. mechanical, photocopying, recording or otherwise, without the prior written permission of the publisher. 


\section{INHOUD}

Voonwoord

1. Mleiding 3

2. Het verschijnsel accountantscontrole 3

3. Theorie rond accountantscontrole 5

4. Discussies over feitelijke toetsing van de theorie 8

5. Tussentidse samenvating 10

6. Onderzoek rond accountanisconirole 11

7. Idecên en suggesties 13

Noten 17

Literatuur 44 



\section{VOORWOORD}

Deze oratie gaat over accountarts, de theorie rond accountantscontrole, en het wetenschappelijk onderzoek naar het "waarom" en "hoe" daarvan. Zeer velen hebben aan de inhoud bijgedragen; direct of indirect. Daarbij denk ik aan talloze cliënten, die ik in de loop der jaren mocht bedienen, en die mij frequent voor nieuwe uitdagingen stelden, aan thun adviseurs en commissarissen" de "meerdiensten"-collega"s en medewerkers zowel in mijn maatschap Deloitte Dijker Van Dien als elders, afwisselend optredend als collega en als concurrent; de wetenschappelijke collega"s, in her bijzonder van de Vrije Universiteit, het Limperg Institunt en de Rijksuniversiteit Limburg; vele studenten in Amsterdam en Maastricht; een brede kring van familie, vrienden, kennissen - zij allen zijn door hun interesse, kritiek, dadendrang en hulp grote stimulansen geweest om over de accountantsfunctie en zijn relatie tot de samenleving voortdurend te blijven nadenken.

I would like to express my sincere thanks to many colleagues of Delloite Haskins + Sells, especially at New York Executive Office; Mr. Theodore F. Bluey, Chief Accountant of the SEC Enforcement Division, and Mr. John Hegarty. Secretary General of the FEE.

Ook onze beroepsorganisatie NTwRA en zijn vele medewerkers ben ik zeer erkentelijk. In het bijzonder geldt dit mevrouw M. Hertzberger-van Aalst, bibliothecaresse; zij was mij zeer behulpzaam met een volledige bibliografie van Th. Limperg jr. en $\mathbb{R}$.A. Dijker. Onze matschapsdocumentalist de heer F. van der Lei heeft mij frequent terzijde gestaan met het soms in ijltempo wereldwijd bemachtigen van literaturr. Prof. drs. Gijs Bak RA en Prof. dr. Jan van de Poel hebben zoveel betekend voor mijn ontwikkeling, dat ik aan hen durfde vragen het concept van deze oratie te lezen. Immers, zonder hun jarenlange intensieve betrokkenheid zou ik hem nooit hebben kunnen schrijven.

Onze Maastrichtse secretaresses Nancy Vandeberg, Sylvia Cox, José van der Poel en Marianne Stijnen zijn bij voortduur zo onmisbaar, dat het verstandig is dat publiekelijk te erkennen. Vanuit Rotterdam hebben Margreet Leydekker en Ingrid Wijnmalen mij kundig bijgestaan.

Mijn kinderen Auke, Nynke en Marike hebben mij geholpen door elementaire vragen over accountants te stellen.

Elke donderdagavond ben ik in Maastricht. Des te geinteresseerder heeft Eefke op alle andere avonden met mij het accountantsberoep besproken en onderzocht. De raakvlakken tussen de medische en de accountantskunde zijn mede daardoor een rode draad in deze oratie geworden. 

Meneer de Rector, Dames en Heren,

\section{1) Inleiding}

Mijn leeropdracht betreft de "Leer van de Accountantscontrole". Mk wil daarom vanmiddag de volgende vragen aan de orde stellen:

1. Waarom is er zoiets als accountantscontrole: wat is het eigenlijk?

2. Hoe heeft de "leer", de theorie van accountantscontrole zich ontwikkeld?

3. Welke vagen zijn belangrijk in het wetenschappelijk onderzoek van accountantscontrole?

Mijn conclusie zal zijn, dat het Nederlandse accountantsberoep aanvankelijk koploper was in de theorievorming rond accountantscontrole: maar dat het later een achterstand heeft opgelopen in de actualisering van de theorie, en de aansluiting bij internationaal onderzoek goeddeels heeft gemist. Ik besluit daarom met enkele constructieve suggesties om het wetenschappelijk onderzoek van accountants en accountantscontrole te stimuleren. Zij, die deze helikoptervlucht te globaal vinden, treffen diverse gevarieerde excursies aan in de voetnoten.

\section{2) Het verschijinsel accountantscontrole}

Een van de positieve punten van de Rijksuniversiteit Limburg is het gezelschap van medische wetenschappers hier. Dat komt goed wit, want de vergelijking tussen huisarts en accountant is redelijk populair" ${ }^{\prime \prime}$ Op meerdere momenten in mijn oratie zult $U$ dan ook medici ontmoeten. Om te beginnen noem ik de oratie van collega Van den Hout over de geestelijke gezondheidkunde. Van den Hout deelt in het begin van deze oratie mee, dat hij niet weet wat geestelijke gezondheid is. Men voelt het gehoor nu denken: wat doe je hier dan? Maar dat blijkt weldra: als Van den Hout uitlegt dat zijn wetenschap zich er eigenlijk op richt geestelijke ONgezondheid op het spoor te komen en te beperken. De geestelijke gezondheidkunde richt zich zo op indirecte wijze op de bevordering wan geestelijke gezondheid, namelijk door te verminderen of weg te nemen datgene wat in de weg staat, wat blokkeert op de weg naar welzijn. Volledig welbevinden is onbereikbaar, maar het beperken van overbodig lijden allerminst ${ }^{2}$.

Deze indirecte benadering lijkt heel bruikbaar. Het is en soort dubbele ontkenning: wegnemen, beperken wat niet of minder wenselijk is. Wat accountantscontrole eigenlijk is en wat accountants doen: dat komen wij wellicht sneller op het spoor als wij ons de simpele vraag stellen: wat gebeurt er als er GEEN accountants zijn? Ik wil dat illustreren met een korte passage uit het Bijbelboek Mattheus ${ }^{3}$, waarin Jezus zijn gehoor een levensles voorhoudt: 
"Het is als een man die op reis ging. Hij riep zijn dienaars bij zich en vertrouwde hun zijn eigendommen toe. Aan de een gaf hij 5000 gouden munter, an een ander 2000 en aan een derde 1000 , ieder naar wat bij ward was. Toen vertrok hij. Onmiddellijk ging de dienaar die 5000 goudstukken had gekregen, er zaken mee doen en hij verdiende er 5000 bij. Zo deed ook de tweede en hij verdiende er 2000 bij. Maar de dienaar die 1000 goudstukken had gekregen, ging een kuil graven en verstopte het geld van zijn heer. Een hele tijd later keerde de heer van die dienaren terug en hij riep hen ter verantwoording. De dienaar die 5000 goudstukken had gekregen, kwam en overhandigde hem nog 5000: Heer, U hebt mij er 5000 gegeven, kijk, ik heb er nog 5000 bij verdiend. Uitstekend, zei zijn heer. Je bent een goed en trouw dienaar. ... Hetzelfde gebeurde met de man, die zijn 2000 goudstukken verdubbeld had. ... Maar toen kwam ook de man die er maar 1000 had gekregen: Heer, ik weet dat U streng bent; ik was bang en ben daarom UW geld in de grond gaan verstoppen. Hier hebt $U$ het weer terug. Jij slechte en luie dienaar! antwoordde zijn heer hem. Je had mijn geld naar de bankiers moeten brengen en dan zou ik het met rente hebben opgevraagd ... Gooi die onbruikbare dienaar eruit, de duisternis in"!

De vraag is simpel, dames en heren: waarom had deze heer geen controlerend accountant aangesteld? Deze economische ongezondheid had toch vermeden, althans beperkt kunnen worden? Want wat was er gebeurd als hier een accountant had rondgelopen? De eerste mogelipheid is deze. De accountant krijgt van de heer de opdracht om met enige regelmaat een controle in te stellen. De heer wil op grond daarvan een rapport wan de accountant, waaruit blijkt of zijn dienaars redelijk met het geinvesteerde vermogen omgaan. Met die opdracht gaat de accoumtant de drie dienaars langs. Hij vraagt hun om verantwoording van hun investeringsbeleid en het rendement dat zij behalen. De eerste twee hebben dat keurig opgeschreven: er staat wat op de bank, er is wat onderhands uitgeleend aan gegoede relaties en een gedeelte is omgezet in koopwat en ook al weer verkocht. Per saldo is het vermogen toegenomen. De accountant gaat dit controleren: hij vraagt aan de bank, of het opgegeven saldo klopt, hij laat de uitstaande leningen bevestigen, enzovoort. De mogelijke technische complicaties in de controlewerkzaamheden bespaar ik $U$ nu. Maar dan komt hij bij de derde. Die heeft het geld dus in een oude sok gedaan, en onder de grond gestopt. U begrijpt: daar komt de accountant achter. Misschien probeert de derde dienaar nog een frauduleus verhaal, dat hij het aan kemnissen heeft witgeleend; maar daar trappen wij niet in.

Conclusie: reeds na enkele maanden krijgt de heer bericht dat dienaar drie de boel geflest heeft, en de heer kan ingrijpen. 
Ex is een tweede mogelijheid, en dat is de gegroeide praktijk. De dienaars weten, dat hun heer een accountant heeft aangesteld, of zal aanstellen. Dat betekent dat de derde dienaar rekening moet houden met een grote kans op ontdekking. Waarschijnlijk zal hij dan of meteen zijn heer wragen om ontheffing van zijn taak als vermogensbeheerder; OF hij zal een risiconijdende investeringpolitiek volgen, en de 1000 goudstukken laagrentend maar veligig beleggen. In beide gevallen werkt de instelling van de accountantscontrole preventief: economische ongezondheid wordt gereduceerd; de kans op een te late ontdekking wan mismanagement wordt beperkt tot een korte tijdspanne PLUS het risico dat de accountantscontrolle faalt. Dat komt gelukkig weinig voor, zodat deze vervelende uitzonderingen meteen de krant halen ${ }^{4}$.

U ziet de parallel met geestelijke gezondheid: het is beter wit te leggen wat accountants proberen te beperken, trachten te voorkomen, willen vermijden; dan te definiëren wat zij willen bereiken, opbouwen, creëren. Als cliënten aAn accountants opdrachten geven met het argument "dat ze rustig willen slapen" dan vragen ze eigenlijk om bepaalde oorzaken van slecht slapen (zoals ongerustheid, zorg, argwaan) zo veel mogelijk te beperken.

Als omgekeerd accountants willen weten, wat "de specifieke problemen van de leiding" zijn", is dat vaak niet zozeer ondat ze deze kunnen oplossen"; maar wellicht kunnen ze helpen deze problemen te beperken.

Dat accountants aan het eind wan hun controle verklaren, of de dienaars een getrouwe voorstelling van zaken hebben gegeven, is als afsluiting zeker belangrijk. En accountants zullen meestal niet kunnen beoordelen, of de dienaars het nog beter hadden kunnen doen. Maar daar gaat het ook niet om. De heren huren accountants in, omdat daardoor beperkt wordt het risico, dat de dienaars het slechter doen dan noodzakelijk is. De kosten van de accountant moeten dus opwegen tegen de beoogde beperking van economische onzekerheden.

\section{3) Theorie rond accountantscontrole}

Wij zijn hiermee, dames en heren, met grote stappen door enkele hoofdlijnen van de theorievorming rond accountants en accountantscontrole gegaan. Wij hebben gezien, dat er iemand was met geld, met een vermogen (de "heer') en dat anderen (de 'dienaars") werden aangesteld om dit geld zo goed mogelijk te beheren. Uit het verhaal bleek, dat er een risico is dat deze beheerders hun werk niet goed doen. De eigenaar van het vermogen realiseert zich dit (meestal niet spontaan, maar door teleurstellende ervaringen, zoals in het verhaal) en stelt een accountant aan om de risico's te beperken. Dit werkt zowel preventief als correctief: ondeugdelijke beheerders, incapabele of frauduleuze managers werdwijnen na constatering 
wan hun gebreken dan wel verbeteren hun prestaties bijtijds. Het wetenschappelijk jargon spreekt hier van principalen (de 'heer'), agenten (de "dienaars") en monitoren (de accountants). Er is sprake van risico" $\mathrm{s}_{\text {, }}$ waarvan omvang en kosten variëren, die dus in functies met variabelen bi te drukken zijn. Er is sprake van een overeenkomsit, een contract word ook wel gezegd, tussen de principaal en zijn agenten (in het geval van de heer en de dienaars een mondeling contract); en de monitor-functie van de accountant moet de mogelijke contractbreuken (slecht beheer, fraude onjuiste verslaggeving, oneigenlike activiteiten) zo snel, goed en goedkoop mogehjk op het spoor komen".

Tot zover is het leven nog redelijk overzichtelijk. Het zall U ook niet verrassen dat de menselijke eigenschap van zuinigheid soms de put pas dempt als het kalf verdronken is, of in elk geval leljik is gevallen. Niets is zo goed voor de bloel van het accountantsberoep als grote maatschappelijke onzekerheid, geillustreerd bij fraudes, beurskrachs en millieuproblemen ${ }^{8}$. Maar nu ik het woord "maatschappelijk" heb genoemd, kunnen wij ons ook realiseren dat de maatschappelijke werkelijkheid waarin accountants hun functie hebben, aanzienlijk gecompliceerder is dan U totnogtoe kon denken. Immers, WIE is eigenlijk die "heer', die "principaal", die de accountant inhuurt? WTE zijn eigenlijk de 'dienaars", de "agenten" die gecontroleerd moeten worden? En WAT verwachten zij eigenlijk van die accountant? Op WELKE wijze kan de accountant bijdragen aan het reduceren wan hun onzekerheden en het beperken van hun risico's? En HOE moet hij daarower verslag uitbrengen, zonder de illusie te wekken dat hij de onzekerheden geheel heeft kunnen wegnemen of alle risico's doen oplossen?

Hoe zijn theorie en onderzoek met deze vragen omgegaan? Het

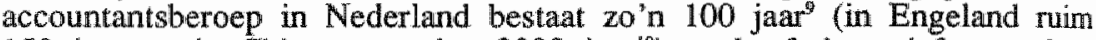
150 jaar en in China meer dan 2000 jaar ${ }^{10}$ ) en heeft intensief over deze vragen gedacht en gediscussieerd. Het lijkt verdedigbaar te stellen dat het Nederlandse beroep aanwankeljjk zelfs koploper was in de theorievorming rond accountants".

De meest bekende zin uit de Nederlandse literatuur over de accountantstheorie is naar mijn mening afkomstig uit een fundamentele artikelenreeks van Limperg. Deze ontwikkelde rond 1930 zijn zogeheten "Leer wan het gewekte vertrouwen". En in 1933 schrijft Limperg: "De normatieve kern van de leer van het gewekte vertrouwen is dus deze: de accountant is varplicht om zijn arbeid zo te verrichten, dat hij de verwachtingen welke hij bij de verstandige leek opwekt, niet beschaamt; en omgekeerd, de accountant mag geen grotere verwachtingen opwekken dan door de verrichte arbeicl gerechtvaardigd wordt ${ }^{\text {af }}$ "U kon hier weer horen die parallel met de geestelijke gezondheid: vermijden, beperken wat NTET gewenst is. Limperg benadrukt, dat de accountant verwachtingen in de samenleving 
over zijn functie NIET mag beschamen; en, voorts, dat hij GEEN te grote verwachtingen mag opwekken. Voor de rest, ongenuancerd gezegd, makk het jiet uit. Doe wat je will, wat je denkt te kunnen, wal men je wrasait. accountant - zolang je degenen die zich op jouw werk verlaten mar niet teleurstelt $^{\text {t3 }}$. Er zijn allerlei mooie dingen te zeggen over de grondslag van de accowntantsfunctie en de bijbehorende beroepsethit: $U$ zou geroerd kunnen worden door betogen over onafhankelijkheid, integriteit, objectviteit, deskundigheid, om nu maar wat kembegrippen van accountantsethiek te noemen ${ }^{14}$. Maar de simpele essentie is: vermijd teleurstellingen. Het is derhalve niet verwonderlijk, dat de Cedrags- en Beroepsregels Registeraccountants, na cen veelheid van ingewikkelde definities, als eerste inhoudelijk artikel een volstrekte negatie hebben: "De registeraccountant onthoudt zich van al hetgeen schadelijk is voor de eer van de stand der registeraccountants ${ }^{\text {t5.5. }}$. Gaat het derhallve toch eens mis, dan voelt de accountant zich hulpeloos, maar schuldig ${ }^{16}$; hij heeft zijn best gedaan, maar in zijn missie gefaald: hij heeft teleurgesteld.

Ik moet hier de verleiding weerstaan om een excursie te maken naar het terrein der psychologie; om met U stil te staan bij de risico's die een dergelijke normering kan veroorzaken als zij te rigide wordt, verinnerhijkt tot een absolute stelregel die het verband met de levende werkelijkheid verliest. Maar ik kan er niet omheen die wel zeer fundamentele vragen te stellen: HOE weet de accountant of hij iemand teleur zal stellen? WELKE normen hanteert hij bij de opzet, uitvoering en verslaglegging over zijn werk? Met WTE praat hij daatrover?

In het verhaal uit Mattheus lijkt dat simpel: stap naar je opdrachtgever (de 'heer') en bespreek dat met hem. Vraag hem wat hij wil en evalueer dat na afloop. Maar in een complexe samenleving is dat lastig. De een zegt dit, de ander dat; sommigen begrijpen wel wat accountants doen, anderen niet of minder. Limperg heeft getracht hierop te antwoorden met de fictie van de "verstandige leek"; later ook wel de "modale gebruiker" "genoemd. Deze verstandige leek was een soort grootste gemene deler van de verwachingen van al diegenen die door de accountant in die verwachtingen teleurgesteld kunnen worden. Maar omdat het een fictie is, ondat men deze leek niet ontmoet ${ }^{15}$, komen in de plaats daarvan de eigen opvattingen. De accountant stelt zichzelf als verstandige leek de vraag hoe hij zichzelf niet teleurstelt. Dat is de irrationele maar in de Limpergiaanse redeneertrant welhaast onontkoombare cirkelredenering.

Er is veel discussie geweest over deze "Leer". Ik moet U die op dit moment helaas onthouden.

In de voetnoten ben ik nader ingegaan op de dissertatie van Bindenga uit 1973. Heel populair vertaald, zei Bindenga mede na inbreng van gedachtengoed uit de sociologie, als het ware dit: "accountant, wees je bewust van de wereld om je heen; bereid je tijdig voor op veranderingen in 
de behoeften van de samenleving; vergroot je deskundigheid, en daardoor je mogelijkheden en enkerning in de narkt". En in Bindenga"s verdere uitwerking herkent men reeds rudimentair de commercięle ontwikkelingen van vandaag de dag.

Het valt dan ook te betreuren dat, naast enige constructieve reacties, Bindenga bestempeld werd tor ketter van de vertrowwenstheorie. Inmiddels staat daar gelukkig tegenover, dat niet elke profeet al tijdens zijn leven erkend wordt".

De kracht van de sterke punten in de vertrouwenstheorie is overigens nog steeds groot; men denke aan de nadruk op de vertrouwensrelatie met de brede kring van hen, die baat hebben bij het accountantswerk; men denke aan de frisse invalshoek van de negatie: wek nooit teveel vertrouwen op. Limpergs verlangen om het accountantsberoep hoog te houden heeft er veel kracht aan gegewen. Maar geleidelijk hoorde men minder de waarschuwing die Limperg was; wart het begrip "vertrouwensman van het maalschappelijk verkeer" bedoeld was als waarschuwing (denk er toch aan dat men vertrouwen in je stelt, beschaam dat niet ${ }^{20}$ ), begon het geleidelijk (tor vandaag aan toe) te klinken als een opdracht ${ }^{21}$. Een opdracht echter, die dar toch gevoed zou moeten worden door nieuw onderzoek, nieuwe theorievorming, nieuwe toetsing. Dat was echter niet zo gebruikelijk: voortdurende toetsing. De Leer van het gewekte vertrouwen is een gaaf voorbeeld wan een (in de jaren dertig zeker niet ongebruikelijke ${ }^{2 z}$ ) deductief-normatieve theorie, met impliciete apriorismen, zonder empirische toetsing. Dat klinkt vreemd: accountants die hun theorie niet toetsen aan de feiten. Laat ik daarom een korte impressie geven van de

\section{4) Discussies over feitelijke toetsing van de theorie}

Er zijn in de twintiger jaren in dit land boeiende discussies gevoerd tussen accountants. Eén van de centrale vragen daarin was: in welke mate moeten wij de praktijk van accountants onderzoeken en van daaruit conclusies trekken met betrekking tot de theorie?

De grote voorstander van zulk praktijkonderzoek was R.A. Dijker. Het voert nu te ver om op het debat uit $1923 / 1924$ in te gaan tusisen Dijker en ene A. Schilder, hoewel de kwalificaties die de heren elkar toedichten buitengemeen aardig zijn. Zo veronderstelt Dijker, dat Schilder zich in te enge kringen beweegt, en dat hij of niet wil zien of een vreemdeling in Jeruzalem is. Wij zullen dit nog nader wirvechten met de familie Dijker ${ }^{23}$.

Hoogtepunt is beslist een debat wit 1927 tussen Dijker en Limperg. Dijker pleit daarin voor enquêtes onder praktiserende accountants, omdat uit eigen onderzoek yan hem was gebleken dat in de praktijk hele andere accountantsverklaringen werden geformuleerd dan de theorie toestond ${ }^{24}$. Uit de enquêtes moest dan blijken, in hoeverre de theorie afstond van de 
geniddelde praktijk; de laatste zou toch min of meer de basis moeten zijn woor de beroepsnomenting.

Dijker pleite dus eigenlijk voor inductief veldonderzoek de conclusies daaruit konden dan tot bijstelling van de theorie en/of aanscherping van de praktijk leiden. Zijn aprioristisch principe maakte hij expliciet en onomwonden kenbaar, namelijk dat een te grote afstand tussen theorie en praktijk tot ongewenste ongeloofwardigheid leidt.

Limperg was hiervan niet erg onder de indruk. Zijn aprioristisch principe was veeleer een beroepsnomering op zeer hoog niveau; de theorie uit de Leer van het gewekte vertrouwen diende hierbij de weg te wijzen. Deze theorie is deductief; zij redeneent op een theoretisch niveau vanuit een beginsel (het opgewekte vertrouwen, wat het objectief vaststand uitgangspunt van de accountantsfunctie wordt geacht); en vervolgens is de theorie ook bewust normatiefs en richtinggevend voor de praktijk. Vanzelfsprekend wordt de praktijk wel betrokken bij de discussies, maar niet empirisch onderzocht en systematisch geëvalueerd. In gewoon Nedenlands: het interesseerde Limperg eigenlijk nauwelijks hoe de praktijk met de theorie omsprong; de theorie was logisch goed, en dus zat veeleer de praktijk bij afwijkingen fout. Kenmerkend is dan ook Dijker's verzuchting in dit debat: "Als ik dit lees en herlees (namelijk een beroemd referaat van Limperg uit 1926, AS) kom ik tot de conclusie: Wat daar staat, is juist, daar valt geen speld tussen te krijgen. Maar als ik kijk naar de praktijk, dan zie ik de tegenstelling weer, het kan dus niet juist zijn" ${ }^{1126}$.

Het idee van praktijkenquêtes en veldonderzoek heeft het (wat mij betreft: helaas) niet gehaald. Ook andere suggesties deed Dijker; zoals het spreken met deskundige derden als de Verzekeringskamer over de verschillende accountantsverklaringen; of het meer op maat naar de wensen van de cliënt verschillende diensten verlenen; of het op minder uniforme wijze rappor teren. Hoe modern wij vandaag dergelijke ideeën ook zouden vinden (voor de vakgenoten herinner ik ewen aan de discussies over Audit Related Services en de Herziening van het Verklaringenstelsel) ${ }^{2 \%}$ : het accountantswezen heeft het destijds niet gewild. Daarmee is de wetenschappelijke ontwikkeling van het accountantsberoep ondergesneeuwd geraakt in dit land. Er is nog wel een enkel boeiend onderzoek gepubliceerd, zoals de reeds genoemde dissertatie van Bindenga in $1973^{28}$, maar over het algemeen vallen de publicaties meer in de categorie ' $\mathrm{kk}$ vind dat...' dan in die van "we found that..."29. Een wrij recente uitzondering was de publicatie in 1987 door het Limperg Instituut van het enquêterapport "Opvattingen over accountants"30; een oproep van Frielink tot empirisch onderzoek had hiertoe geinspireerd.

Nu kan men zeggen: waarom die nadruk op onderzoek? Het praktische accountantsberoep heeft een naar aanzien, aantal en inkomen gemeten ${ }^{3 .}$ bloeiende ontwikkeling doorgemaakt: het woert een geinstitutionaliseerd overleg met werkgevers en werknemers over beginselen woor het opstellen 
Wan jaarrekeningen, er het is ook op allerlei andere plaatsen betrokken in prakische dialogen. Dus wastom nu meer doen dan goed onderwijs en deugdelijke voorlichtirg geven, goede internationale aansluitingen houden en pragmatische richilinen opstellen?

Welnu, er zijn diverse inhoudelijke argumenten te noemen, die het woor accountants relevant maken om meer fundamenteel na te denker. Bijyoor. beeld, dat de landelijke examens woor accountantscontrole slechts beperkt van doen hebben met de praktijk wan de afgestudeerde, terwijl er daardoor aan zoveel belangrijker zaken te weinig aandacht gegeven kan worden in de opleiding. Bijvoorbeeld, dat de snelle verheviging van de concurrentie in Europees verband als gevolg van de liberalisatie van goederen en diensten wel dwingt tot een goed inzicht in het bestaansrecht van de accountantsfunctie ${ }^{32}$.

Bijvoorbeeld, dat de instelling van de Commissie Geelhoed illustreerde hoe snel geconsolideerde posities ter discussie kunnen komen ${ }^{33}$. Bijvoorbeeld, dat de ontwikkelingen bij de veelzijdige nationale en internationale cliêntele zo snel gaan, dat een daarop aangepaste dienstverlening een ander type accountant vergt dan ons uit het verleden is aangereikt ${ }^{34}$. Bijvoorbeeld, dat de overlueid in landen als Engeland en de Verenigde Staten zich op indringende wijze met het beroep is gaan bemoeien ${ }^{3 s}$, en de accountantsorganisaties daar dwong tot zeer snelle reacties.

Naast deze inhoudelijke argumenten zijn er ook pragmatische. Immers, als de accountantsopleiding terecht de pretentie wil bewaren een wetenschappelijke opleiding te zijn: welk excuus heeft zo'n opleiding dan om niet volop an onderzoek te doen? Of ook: hoe behoudt een universitaire opleiding zijn autonomic, anders dan door de voeding vanuit eigen en onafhankelijk onderzoek? En anders misschien nog: hoe wil deze opleiding de dialoog met het buitenland voeren, in het bijzonder met collega's uit de Verenigde Staten, waar al enkele decennia een indrukwekkende researchpraktijk is opgebouwd?

\section{5) Tussentijdse samenvatting}

Tot hiertoe is mijn verhaal als volgt kort samen te vatten. Accountantscontrole is ontstaan, omdat (groepen van) mensen met elkaar zakelijke afspraken maken. Er zijn risico's gebleken voot de contractpartijen, dat de ander de afspraken onvoldoende nakomt. Partijen hebben er daarom belang bij dat een onafhankelijke en deskundige derde hun onzekerheid daarover beperkt. Accountants doen dit door na te gaan, of de berichten die de ene partij over zijn gedrag aan de ander stuurt, kloppen met de feiten en/of afspraken. Accountantscontrole is dus een functie van de afspraken tussen partijen en de daaraan verbonden onzekerheden; naarmate het product wan de waarde der afspraken en de onvang van de onzekerheden toeneemt, 
word de behoefte aan controle groter. De theorievorming rond de accountantscontrole heeft terecht gezien, dat het terugdringen van onzekerheden door accountants staat of valt met vertrouwen; het vertrowwen dat partijen hebben in de effectiviteit waarmee de onzekerheden beperkt worden. Hertoe is nodig, dat zowel partijen als accountants een helder beeld hebben van elkaars behoeften en beperkingen. De theorie alhier heeft de invulling van dit beeld echter teveel door de accountant zelf laten gebeuten. Omdat empirisch onderzoek minder nodig werd geacht, heeft het Nederlandse accountantsberoep een achterstand opgelopen in de actualisering van de theorievorming en de aansluiting bij internationaal onderzoek goeddeels gemist.

\section{6) Onderzok rond accountantscontrole}

De vraag ligt voor de hand: waar gaat het dan over in dat onderzoek? Ik zal UW geduld niet beproeven met een poging tot uitputtende opsomming: dankzij recente publikaties uit buiten-en binnenland (waaronder de oraties uit 1988 van Van de Poel en Feenstra) is daar voldoende materiaal voor beschikbarr ${ }^{36}$. Onze onderzoeksagenda $\mathrm{kan}$ dus slechts een selectie daaruit zijn. Deze selectie is enerzijds ontstaan uit een mengsel van persoonlijke interesse en het zoeken van aansluiting bij thema's, die ook internationaal perspectief lijken te bieden. Anderzijds, getoetst aan de inhoudelijke argumenten die ik kort hiervoor noemde, zou deze onderzoeksselectie moeten leiden tot publicaties, die relevant zijn voor de praktijk van de moderne accountant; de economische analyse van zijn functie en de toekomstmogelijkheden van het beroep; alsmede bouwstenen moeten aandragen voor vernieuwing van onderwijs en vaardigheidstraining.

Simpeler gezegd: ons onderzoek moet zowel voor het accountantsberoep en zijn clièntele, als voor de onderzoekers interessant zijn. Laat ik enkele thema's noemen.

1. Ten eerste noem ik de vragen rond de afspraken tussen de verschillende partijen. Het gaat dan over vraag en aanbod, ontwikkelingen in de markt voor accountantsdiensten. Daar zijn heel concrete vragen bij, zoals: op welke gronden selecteren cliënten accountantskantoren? Waarom wisselen $z \mathrm{e}^{37}$ ?. Waarom en met welke inhoud stellen partijen schadeclaims tegen accountants in, en welke lessen zijn daaruit the trekken? ${ }^{38}$ ? En nog een ander gebied: welke relatie is er tussen de toenemende regelgeving en de groei van accountantsdiensten? Over deze vragen lopen diverse promotieonderzoeken alhier ${ }^{39}$.

2. Ten tweede noem ik het thema "onzekerheden". Het NIwRA heeft ons gevraagd om afstudeeropdrachten rond dat thema te begeleiden. Het is boeiend, omdat het enerzijds raakt de bestaansgrond van accountants en 
anderzjos de kern van hun inhoudelike werk. (Men zou ook kunnen zeggen, in Limpergians jargon: het is het overgangsgebied van functie natar tak). Daaronder vallen ook de definities van accountantscontrole" en "auditing". Daturonder vallen voorts de veranderingen in het accountantsfunctioneren en in het vakgebied; men denke aan nitbreidingen ruar onzekerheden rond miliewwerankwoordingen, softwarebetrouwbaarheid, frandebestrijding. Beroepsethiek, de grondslag voor het vermijden van teleurstellingen, kan hier ook gerubriceerd worden ${ }^{\text {sk }}$.

3. Ten derde: de oordeels- en besluitvoming door accountants. Wat gebeurt er nu precies in dat koppie van een accountant? Wat is het geheim wan de smid? Wat is een expert, wat is expertise eigenlijk? Diverse onderzoekers, ook van buitenlandse komaf, zijn hier intensief bezig om (onder meer via protocolanalyses) tot expentsystemen te komen $^{4 !}$.

In dit verband noem ik opnieuw de medici. Onlangs promoveerde Boshuizen aan deze uniwersiteit op en onderzoek naar medische expertise ${ }^{4}$. Haar model van expertkennis in drie lagen (namelijk kennis van basisvakken, ziaktescripts en herinneringen aan concrete patiënten) gaf ons andeiding on de reeds bestaande contacten met de vakgroep onderwijsontwikkeling en -research te intensiveren met het oog op mogelijke synergie. (Owerigens merk ik nog op dat ook theologen en psychiaters hier mee bezig zijn ${ }^{43}$ ).

Er is op dit gebied ook inzake accountants veel international onderzoek gepubliceerd" "Wat mij daarin - geholpen door veel collega" $\mathrm{s}^{45}$ - opvalt, is het toenemende unzicht in, en begrip voor, de complexiteit van de oordeelsvorming door accountants. Simpele expertsystemen vragen reeds vele honderden beslisregels. Aanvankelijk werd in publikaties wat fronsend gesproken over de vuistregels (heuristieken) die accountants hanteerden; het leek op willekeur, eenzijdigheid, beperkte rationaliteit.

Dat is het natuurlijk ook, maar misschien is dat nu juist wel zo'n stukje geheim.

Als we daaraan toe voegen complicerende factoren als het beslissen in team- of groepsverband, wordt het nog enkele malen lastiger. Maar echt ingewikkeld wordt het in het spanningsveld van de cliënt-relaties. Het is mijn overtuiging, dat deze context nog teveel ontbreekt in het onderzoek ${ }^{46}$. Om voldoende betrouwbaar en relevant voor de praktijk te zijn $_{*}$ is het nodig dat simulaties en veldwaarnemingen daar terdege rekening mee houden"?

Dat wil niet zeggen dat er ook nu al niet veel behartigenswaardigs is gepubliceerd. Daaruit blijkt, dat ook accountants gevoelig zijn voor allerlei valkuilen tijdens hu oordeelsworming. Dat zou best eens wat meer in de opleiding ervaren mogen worden. Er is voldoende oefenmaterialal ${ }^{48}$ ! 
4. Een vierde onderzoeks gebied is de communicatie tussen accountants an vele betrokkenen. In het verleden is wel degelijk door accountants geprobeerd om nomad Nederlands te spreken wan nomale lengte. De eerste accomntantsverklaringen van Klynveld bij de $\mathrm{N}$. $\mathrm{V}$. Philins in de dertiger jaren besloegen zelfs anderhalve bladzjde, en werden in de Engelse vakpers met het nodige respect begroet. In Nederland viel de vakpers gedeeltelijk samen met Limperg; diens reactie was afkeurend" Ook meer recent zijn wel pleidooien gevoerd om accountants wat meer

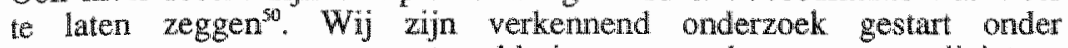
consumenten van accountantswerklaringen, on hen meer expliciet te vragen naar hun waardering daarvoor. (Tevens rijst de vraag of de essentie van de functie, namelijk het beperken van onzekerheden, wel voldoende doorgewerkt heeft. Accountants spreken mu in positieve zin over "een getrouw beeld", maar kunnen dat alleen watrmaken door naar een uitgebreid stelsel van afspraken en conventies te verwijzen, waarbinnen dit beeld getrouw is; in zoverre is er dan een (nogal ingewikkelde) zekerheid. Wellicht zou het eerlijker zijn, als de accountant meldt dat het beeld niet onjuist is ${ }^{31}$ ).

In dit communicatieveld past ook de dialoog met vele gasten uit beroep en samenleving tijdens onze vrijdagmiddagbijeenkomsten.

Hoe kort ook, het is al weer een hele lijst ${ }^{52}$. Hoe reeel is de kans, dat het zinvol is? Veranderen leven en praktijk niet voortdurend, en holt het onderzoek daar niet als een veroordeelde Griekse held achteraan?

Laat ik daarom afsluiten met enkele

\section{7) Ideeën en suggesties}

Uiteraard verandert het leven en de praktijk bij voortduur. Maar dat doen de onderzoeksthema's en de uitkomsten daarvan ook. Laten we zeggen, dat er een voortdurende wisselwerking is tussen theorie en prakiijk; een permanente dialoog tussen wetenschap en samenleving. Een steeds aanwezig spanningsveld ook, trouwens. Maar zolang de practicus nog de theoreticus beschimpt, omdat deze eerst maar eens in de praktijk moet komen kijken; en omgekeerd de wetenschapper tegen de praktijkman opmerkt, dat deze toch eens meer over serieus onderzoek moet nadenken, zolang houden we elkaar wel wakker ${ }^{33}$. Dergelijke discussies heb ik enkele jaren met genoegen mogen voorzitten in de LI-VOMAR werkgroep van het Limperg Instituut.

1. Want dat is het eerste idee, dat ik met betrekking tot het onderzoek van de accountantscontrole, de audit research, bij $U$ neer wil leggen. Theorie en praktijk moeten gestructureerd met elkaar bezig blijven. 
(A) ik de discipline der accountanisconirole met een aan Van Doom ontleende tern mag aanduiden als een interventie- of actorwetenschap, is daamee ook gezegd dat theorie: en praktijk een zinloze tegensteling is. De treflectie van de theorie betreft immers de interventie in de praktijk; en ondat deze zich weer onwwkkelt in dialoog met ontwikkelingen in het praktijkveld en in de theorie, zijn theorie en praktijk Siamese tweelingen voor ons vakgebied. Maar het kan geen kwaad dat ook goed in te bedden). Daarom is het gebied der accountancy aan deze Universiteit ook geen aparte vakgroep, maar ingebed in de Sectie berichtgewing. Daar zitten de full time wetenschappers, zal ik maar zeggen. De wetenschap der accountantscontrole - ik zou zelf liever wan accountantskunde spreken ${ }^{55}$ - wordt dan voortdurend bevralagd en gevoed door de bedrijfseconomie, maar is tegelijk door de aard van deze kunde ditect gebonden an de praktische werkelijkheid.

2. Het tweede idee betreft de organisatie wan het onderzoek. Ten derde en latste male raadpleeg ik een medicus. Ditmaal betreft het de oratie wan Knotmerus, die het heeft over de dialectiek tussen de praktizerende huisarts en de wetenschappelijke onderzoeker ${ }^{36}$. Van hem heb ik minstens twee dingen geleerd. Ten eerste, dat onderzoek in een huisartsenpraktijk nog veel gevoeliger moet liggen dan in een accountantspraktijk; accountants kunnen daar dus geen excuus vinden. Ten tweede, zijn beschrijving van een soort onderzoeksnetwerk met huisartsen in deze regio. Door het opbouwen van duurzame contacten met praktijkmensen moet het ook voor de accountantskunde mogelijk zijn research op reguliere basis te organiseren.

3. Ten derde, in aansluiting hierop, het spanningsveld concurrent versus collega. Ik vermoed dat dat bij de medici minder speelt. Maar accountants zijn zowel vakman als ondernemer; als vaklui zijn het ook valkbroeders, maar als ondernemers zijn het concurrenten. Toen wij met onderzoek startten vorig jaar, kon dan ook van verschillende kanten scepsis vernomen worden: er zou vast niemand willen meedoen, wit vrees voor het prijsgeven van concurrentiegevoelige informatie. Deze gedachte bleek voorbarig. Enkele voorbeelden zijn de volgende:

- Op de NIVRA-Najaarsconferenties 1988 deden ruim 100 accountants met groot enthousiasme mee aan een onderzoek naar hun besluitvorming temidden van geleidelijk opgevoerde spanning en complexiteit. Bij de evaluatie verklaarden zij zich garne bereid on een wolgende keer weer mee te doen ${ }^{35}$.

De LI-VOMAR werkgroep van het Limperg Instituut heeft een schriftelijke en mondelinge enquête uitgevoerd onder de bureaus waktechniek wan accountantskantoren en hun daarbij gevraagd naar de kantooropvattingen over en -benaderingen van materialiteit en 
risico-analyse. Zonder uitzondering toonden alle grote Nederlandse en Amerikaanse kantoren zich bereid mee te doen ${ }^{3}$.

- Het expert systeem onderzoek, dat aan deze universiteit met betrekking tot accountants wordt uitgevoerd, wordt (ook financieel) gesteund door het Limperg Instituut. Het verkreeg de onderzoeksmedewerking van een kleine dertig drukbezette accountants van drie grote kantoren.

- Een onderzoeksidee alhier naar de betekenis van en accountantsverklaring in een consumentenadvertentie riep spontaan enthousiasme op bij een docent, een collega-wetenschapper wan marketing, enkele studenten, het betreffende accountantskantoor en diens cliënt.

De hoofden c.q. medewerkers van diverse bureaus vaktechniek van grote accountantskantoren toonden zich bereid aan onze studenten hun specifieke controlemethodieken toe te lichten.

Een voorstel aan de Duits-Nederlandse accountantsgespreksgroep om een brainstormingsproduct van de LI-VOMAR werkgroep van het Limperg Instituut met hen verder uit te werken, werd buitengewoon enthousiast begroet.

In één zin: waar een wil is, is ook onder accountants zeker een weg. Daar blijven wij, empirisch bemoedigd, wan uitgaan.

4. Ten vierde: hoe worden onderzoeksprioriteiten bepaald en met het veld afgestemd? Het was opvallend in sommige reacties op vragen van de eerder genoemde LI-VOMAR werkgroep an de bureaus vaktechniek, dat de respondenten onderzoek op prijs stelden dat grote lijnen trok en de stand wan zaken in het professionele veld in bredere kring toegankelijk maakte. Men had minder behoefte aan bestudering van onderdelen, die gedetailleerd op de praktijk in zouden gaan, met als motivering dat het kantoor dat zelf well zou invullen. (In concreto zat men bijvoorbeeld niet algemeen te wachten op richtlijnen voor de te hanteren materialiteitsnomen bij de controle. Dat klinkt als een logische taakverdeling, maar was voor sommigen toch even verrassend). Dit vragt om een onderzoeksagenda, die enigszins is afgestemd met de zusterfaculteiten en de accountantskantoren. Men vergelijke het Engelse voorbeeld ${ }^{59}$.

Het komt mij woor, dat het Limperg Instituut met name een taak zou kunnen hebben in de periodieke afstemming tussen deze betrokkenen. Wat onze Universiteit betreft, betekent dat dan een overleg met minstens de gehele Sectie Berichtgeving van de Vakgroep Bedrijfseconomie.

5. Ten vijfde: waar tot nog toe voomamelijk sprake was van activiteiten binnen Nederland, zien wij dat als wat te beperkt. We zijn daarin gelukkig niet de enigen binnen ons vakgebied; ook elders wordt de blik Europees en globaal gericht ${ }^{\text {th }}$. Zeker in Maastricht achten wij grensoverschrij- 
dend onderzoeksverkeer nodig. In dit verband zijn we verheugd over de goede contactén thet de Fédération des Experts Comptables Européens, de Europese accountantsorganisatie. Ook met onderzoekers in de Verenigde Staten en elders zijn de persoonlijke contacten en witwisseling groeiende ${ }^{\text {in! }}$.

Niet voor niets, dames en heren, viel nogal eens het woord 'wij'. EF gebeurt hier veel, maar dat kan alleen in teamwork met velen. Een hooglerat met $25 \%$ aanstelling kan zonder hun vitdagingen en medewerking weinig. Immers, zoals Frielink eens schreef: "een accountant is ook maar een mens". Dat is in elk geval een interessante hypothese ${ }^{62}$. Voor deze hypothese en voor al het voorafgaande moge gelden: "Onderzoekt alles. . . . behoudt het goede" 
1. De vergeliiking arts-accountant

In een debat in 1938 met NJ. Polak over de aspecten "techniek" en 'advies' trekt Limperg een vergelijking met de medische opleiding om te illustreren dat men deze twee aspecten niet teveel van elkaar moet scheiden (NIVA, 1938, p. 168).

Bindenga (1973) trekt met name in hoofdstuk IV-4 enige parallellen tussen het oordelen van de accountant en de arts in het licht van het maatschappelijk belang van hun functies (pp. 177, 186/7). Groeneveld (Limperg/Groeneveld, 1976) bekritiseert dit op p. 38, en meent, "dat Bindenga hier alle scherpte van betoog verloren heeft" (waarbij "hier" een understatement is in Groenevelds kritiek). Beziet men echter de actuele discussies in de medische ethiek, bijv. over de keuzes die de samenleving moet maken bij hel al of niet geven van dure medische behandelingen, dan moet men constateren dat deze discussies in de opvattingen van Bindenga reeds in de kiem voorzien en voorspelbaar waren. (De beschouwingen van Van Doorn (1988) over het medisch professionalisme als onderdeel van het interventieprogramma van de Verlichting (pp. $156 \mathrm{vv}$.) brengen dit in een boeiend kader).

Desalniettemin heeft de vergelijking zijn beperkingen, bijv. vanwege het openbare karakter van accountantswerklaringen en de (niet altijd vrijwillig aanvarde) controlerelatie tussen gecontrolleerde en accountant. Fellingham en Newman (1985) schrijwen in een pleidooi voor een speltheoretische benadering van het accountantsproces, dat bij de ontwikkeling van expertsystemen de parallel met het diagnosesysteem van de arts zijn beperkingen heef: "But there is a critical difference between medicine and auditing: illnesses do not deliberately attempt to conceal symptoms; audirees may." (p. 648). Toch ligt ook hier een mogelijke overeenkomst, namelijk het te goeder trouw en onopzettelijk verborgen houden wan gegevens. Wellicht is de parallel tussen controlerend accountant en keuringsarts iets meer van toepassing; Kabela (1988) wijst erop, dat bij een psychiatrisch keuringsonderzoek de keurend psychiater zijn positie als keurend specialist (in tegenstelling tot behandelend specialist) noet duidelijk maken aan de verzekerde.

2. Van den Hout (1988), pp. 1-6.

3. a) Bijbelse parabels en empirisch onderzoek

Mattheus 25: 14-30 (enigsins verkort weergegeven), in: Bijbel (1984). Bij de kewze van deze parabel zijn twee opmerkingen te maken. Ten eerste, dat deze parabel in het wetenschappelijk jargon 
wellich het best getypeerd wordt als "anecdote" $\mathrm{d}$ w.z. een tekst met een relevante illustratie wan een stelling of hypothese, warran de warde nist empirisch getoetst is. De vrag is dan wervolgens meteen, hoe 2000 jaar geleden empirische toetsing verliep. Verluaten, parabels waren toen een bijzonder belangrijk communicatiemidde: men legde er zijn visie op een levenswarheid in neer, en gaf hes vervolgens in discussie. Anderen namen het mee, woegden er hun eigen ervaringen aan toe, en geleidelijk werd zo"n parabel een meer objectieve en door velen "getoetste" beschrijwing van warheld. Men moet dan ook niet verrast zijn, dat originele schriftehike bijbelteksten werschillende auteursstjlen lijken te weerspiegelen; hieruit blijkt juist het toetsingsproces.

Dit proces roept vergelijkingen op met iemand, die een onderzoek doet, daarvan eerst in kleine kring versiag doet, zijn verhaal op grond van de kritiek bijstelt, er aen working paper of research memorandum van maakt en dat presenteert op een congres; de kritiek daar verwerkt hij weer, waarna een artikelconcept volgt; dit doorloopt reviews van de redactie van het aangezochte tijdschrift; wederom bijstelling, waama publicatie. Dan de reacties afwachten, en daarmee weer verder. Essentieel is de systematiek en continuiteit in dit proces.

\section{b) Hel begrip "getrouw"}

Een tweede aspect is de keuze van de tekst. Deze was reeds bepaald voordat mij bleek dat ook Bac (1989) zijn oratie van een bijbeltekst had voorzien (p. 5). De tekst is gekozen wanwege de illustratieve waarde ervan. Daamaast is het interessant, dat aan deze passage (Matheus 25:23, in een oudere vertaling sprekend van de 'goede en getrouwe dienstknecht') ons begrip 'getrouw' is ontleend. In het begin wan de vijftiger jaren bestond namelijk behoefte aan een goede vertaling van 'true and fair' voor de accountantsverklaring in het Nederlandstalige jaarverslag van de Koninklijke/Shell. Een bijbelgetrouwe collega (E.J. Flipse) schoot toen deze bijbelpassage te binmen, en "getrouw" bleek goed te vallen (zie De Jong, 1975 en Schoonderbeek, 1984, p. 176).

Vervalgens treffen we in Stewart (1988) een korte, maar boeiende achtergrondschets aan van de keuze in Engeland voor 'true and fair". Men achte in 1945 "true and correct" niet adequaat, gezien het weelvuldig voorkomen van geheime reserves. Bij "true and fair" werd neer numte gevoeld. Stewart betoogt dan, dat het begrip whoud krijgt en herkrijgt in een dynamisch historisch proces. Hij concludeert, dat een "me and fair view" een "impossible possibility" is (de term is geleend van de Amerikaanse theoloog Niebuhr, maar doet denken aran Van den Hout; deze schrijf op p. 7: "Misschien moet volledig welbevinden simpelweg begrepen worden als ideaal 
waarvan we op voorhand weten dat we het niet kunner kennen en nooit zullen bereiken dock dat desondanks nagestreefd kan worden ${ }^{\text {ti }}$ ).

Met dit alles in gedachten is het interessant om ons dan nog even af te vagen, wat "getrouw" in de genoemde bijbeltekst betekent. In de originele Griekse tekst staat "pistos". Dal is een kernwoord in het hele Nieuwe Testament, en wordt ook vaak wertaald met 'gellovig'. Het staat voor de relatie tussen mensen of tussen God en mens, waarbij men op elkaar aankan, op elkaar rekent, elkaar vertroww, in elkaar gelooft. Een 'getrouwe" dienaar is dus een dienagr die zich gedragen heeft conform de verwachtingen, conform hel parmership tussen hem en zijn heer, kortom: die zich aan de afspraken en contracten gehouden heeft. Daaruit blijkt hoezeer dit begrip past in de theorie rond de accountantscontrole. Het illustreert tevens, dat het gaat om betrekkingen tussen mensen. Als een jaarrekening een 'getrouw beeld' geeft (hoe "impossible' dan ook), moet dat inhouden dat het een adequate weergave is van de uitvoering van afspraken nussen de partijen (in deze zin ook Wilschut, 1987 en 1988). In die zin lijkt Schandl's omschrijving van auditing als een "human evaluation process" een goede typering (geciteerd in Abdel-khalik en Solomon, 1988, p. 96 ).

4. Zoals in FEM van 8 april 1989, waar onder de kop "Accountants gooien er soms met de pet naar" twee gevallen worden besproken, waarin volgens de auteur onjuste verklaringen door accoumtants zijn gegeven. In hetzelfde artikel wordt dan gesteld: "en de minister en de belegger gaan af op de verklaring van de accountant die in Nederland het kwaliteits-aureool van een Zwitsers horloge draagt".

5. Citaat uit "Audit Plus" (1988), pp. 25 en 58.

6. Zo wordt in de "Accountant-Adviseur" van februari 1989 de volgende stelling van het CDA. Tweede Kamerlid Schartman geciteerd: "Accountants, die zijn opgeleid om andermans zakelijke problemen op te lossen, volharden bij voortduring in het als onoplosbaar voorhouden van hun eigen beroepsproblemen". Als ze daar dus NIET voor opgeleid zijn, wordt de situatie al wat helderder.

7. Deze begrippen zijn afkomstig van de zogeheten agency-theorie. Korte en heldere overzichten zijn ondermeer te vinden in Bouma (1988, met name deel 2), Dassen (1989), Douma (1987), Van de Poel $(1988,1989)$, Langendijk (1989). Daarin komt ook aan de orde de accountant als zelf agent zijnde, eventueel met meerdere principalen. Fundamenteel zijn o.a. Jensen en Meckling (1976) en Jensen (1983). Morris (1987) behandelt relaties tussen agency theory 
en signalling theory. De motivational theory (gememoreerd bij Taylor en Glezen, 1988, p. 11), sluit hierbij aan.

8. Voorbeelden hiervan in De Vries (1985, o.a. pp. 34-36, Pincoffsaffaire; 92/93, diverse banken); Mautz en Sharaf (1961, pp. 240 vv.); een citaat: "There seems no need to recount the unfortunate history of some of the early joint stock companies in England, the wave of speculation and even fraud that almost stopped their formation, and the consequent intervention of Parliament by the passage of the various Companies Acts which, among others, provided for independent audits, a pattern of financial statements, and the rights and duties of the auditors" (p. 242). In Ricchiute (1988, pp. 9-11) en Taylor en Gilezen (1988, pp. 117 vv.) worden ontwikkelingen in de Verenigde Staten kort geschetst. Wat betreft de milieu-audit geven Buisman en Van Marion (1989) een recent overzicht van ontwikkelingen en enige relevante literatuur.

9. De Vries (1985), Metzemaekers (1983), Modderaar (1934).

10. Voor Engeland, zie; The History (1966), Hogeweg (1929), Modderaar (1934), Watts en Zimmerman (1983). Voor China: Center for IAD (1987). China is interessant, omdat hier van een redelijk ontwikkelde accountantsfunctie sprake was. Men komt in de bij de noten $8 \mathrm{t} / \mathrm{m} 10$ genoemde literatuur ook verwijzingen tegen naar de accountantsfunctie in het middeleeuwse Engeland en het Romeinse Rijk.

11. Het is tenminste opvallend, hoe de Engelse vertaling van Limperg's artikelenreeks uit 1932/33 (zie: Limperg Instituut, 1985) Flint (1988) tot groot enthousiasme over Limperg's vertrouwenstheorie brengt. Het Amerikaanse principiële standaardwerk wan Mautz en Sharaf (1961), dat bij diverse auteurs van auditing handboeken uit de U.S.A. de enige basisreferentie is (zie bijw. Guy en Alderman, 1987, p. 40; Ricchiute, 1988, p. 5; Taylor en Glezen, 1988, p. 7) bevat aan Limperg verwante gedachten, doch is pas zo'n 30 jaar later geschreven.

12. Limperg (1932/33), p. 235.

13. Limperg, a.w. p. 235: "Deze eenvoudige stelregel geldt onathankelijk van de inhoud der verwachtingen; of die omvangrijk dan wel bescheiden zijn, in geen geval mag het verkeer in die verwachtingen worden teleurgesteld. In haar normatieve kern geeft de Leer geen stellig voorschrift omtrent hetgeen de accountant in elk bijzonder geval te doen heeft; zij lat hem zelf daarover als vakman de beslissing. Doch als richtsnoer voor die beslissing geeft zij hem 
dit algemene voorschrift, gegrond op de owerweging, dat de effectieve inhoud der functie, haar witwerking dus in het verkear, bepaald wordt door het door haar opgewekte vertronwen".

14. Schilder (1989), pp. $12 \mathrm{vv}$.

15. GBR (1988), artikel 5. Men zou wellicht verwachten, dat hier had gestaan: de registeraccountant onthoudt zich wan al hetgeen schadelijk is voor het maatschappelijk verkeer, of zoiets. Door de systematiek van de huidige GBR is dat echter niet mogelijk, pas vanaf artikel 8 komen de beroepsregels, die gelden voor registeraccountants die ook daadwerkelik als accountant optreden (Ygl. Frielink, 1984, p. 18).

Desalniettemin is het interessant om te zien welke aanbevelingen de zgn. "Commissie Jorritsma" (belast met de inventarisatie van wenselijke herzieningen van de GBR) zal doen. Opvallend is bijvoorbeeld de herziene Code of Professional Conduct van het Amerikaanse accountantsinstituut (1988), die begint met zeer positieve vitspraken over het dienen van 'the public interest" (article II).

16. Dit is een bewuste referentie aan Aleid Schilder (1987). Zonder nu te dramatiseren, moet toch erkend worden dat enig verband aanwezig is, als Aleid opent met de zin: "Tk ben altijd bang dat ik fouten maak" (p. 13). Accountants zijn, geloof ik, bepaald niet "altijd bang", maar ze kunnen van fouten wel erg schrikken. Verfrissend is het dan, als Van Stokkon schrijft (in een artikel over het kritisch rationalisme van Karl Popper): "Op deze wijze ontstaat er een geheel andere intellectuele verantwoordelijkheid. Doel is niet: wees een autoriteit; scherm haar tegen anderen af. Weet alles op je vakgebied. Maak geen fouten. Maar het doel is: stell je feilbaar op. Durf fouten toe te geven. Natuurlijk blijft het onze opdracht om fouten naar mogelijkheid te vermijden, zo voegt Popper hieraan toe. Maar om ze te vermijden moeten we ons er bewust van worden hoe moeilijk het is ze te vermijden... De oude beroepsethiek is daarom intolerant en star. Daartegenover plaatst Popper een nieuwe dynamische beroepsethiek. Stelregel is dat we van onze fouten moeten leren..." (Van Stokkom, 1988, p. 7).

17. LAC (1985), pp. 32,67.

18. De "Yerstandige leek"

Over de "verstandige leek" is veel geschrever. Fundanenteel was reeds de analyse van Pinkhof (1933), die in een evenwichtig artikel over de verschillen tussen Belle en Limperg concludeert, dat dit begrip een "subjectief beeld, dat mij min of meer vagelijk voor ogen zweeft" is; met een verwijzing naar Goethe noemt Pinkhof de 
verstandige leek de "Geist der Zeiten" (p. 219). Daarentegen geeft Kleereikoper (1971) een zeer levendige beschrijwing van de verstandige lexk; hij had hem wargenomen, horen spreken en personifieerde hem als "de financiele pers". Aan deze verstandige leek mag en moest "behalve een zekere mate van verstand ook een zekere mate wan redelijkheid" worden toegeschreven (pp. 1026/1027). Dit doet ook denken an de "redelijke figurur van Limperg (1965, p. 81) en de "intelligente buitenstaanders" bij Frielink (1980).

Vele jaren later werklaarde Wilschut (1988) de verstandige leek "morsdood"; men kan op deze opmerking tegen hebben dat hij suggereent dat genoemde leek oolt bestaan heeft.

Ophof (vooir wie Wilschuts artikel geschreven was en die het ook grondig gelezen heeft (zie Ophof, 1988) heeft dit owerlijdensbericht genegeerd en zichzelf gepresenteerd als de verstandige leek (NRC, 22 februari 1989). Dit ontlokt Dassen (1989) de opmerking: "Zeer incidenteel kan nog een exemplaar van "de verstandige leek" worden wargenomen. Zo pleegt Prof. mr. dis. H.P.J. Ophof zich als zodanig te presenteren... De reacties die hij oproept binnen kringen wan accountants doen evenwel twijfel rijzen aan de normatieve invloed die hij heefi op hun gedrag" (voetnoot 12). Uit Dassen's bewoordingen spreekt overigens een te waarderen verlangen om deze en anclere verstandige leken in het oog te houden; zij het dat op het in vogelaarskringen gebezigde begrip "waamemen" valt aan te merken, dat hier de dialoog der ontmoeting ontbreekt. Maar misschien was dat nu juist typerend voor het omgatan met verstandige leken.

19. Discussie over de "vertrouwensleer", Bindenga's dissertatie

Een literatuurverwijzing is tamelijk arbitrair, omdat in onnoemelijk veel publicaties direct of indirect gerefereerd is aan de "vertrouwensleer". Zonder enige pretentie tot wolledigheid noem ik toch enkele namen die mij meer dan gemiddeld zijn bijgebleven uit deze discussies: de inleiding van Dijker uit 1927, en het daarop volgende debat met o.a. Limperg; het proefschrift van Belle (1931/1961); het pré-advies van A. Mey in 1936, met discussie van o.a. Dijker; Bindenga (1973, 1975); Bak (1975); Groeneveld (Limperg/Groeneveld, 1976); Blokdijk (1979); Frielink (1976, 1980); Wilschut (1988). Zie ook het overzichtsartikel van Nordemann (1984).

Enkele kanttekeningen hierbij nog; op andere punten kom ik bij volgende voetnoten terug.

Eén wan de waardevolle punten van Bindenga's dissertatie (1973) was m.i. de inbreng van gedachtengoed nit de sociologie inzake het proces van institutionalisering. Als ik dat even heel populair vertal, 
is de les daaruit: accountant, wees je bewust van de wereld om je heen; bereid je tijdig voor op veranderingen in de behoeften van de samenleving; vergroot je deskundigheid, on dasrdoor je mogelijkheden en erkenning in de markt. Bindenga lllustreert dit met de opbouw van een toekomstperspectief als een zevenklapper: "1. De functie van de openbare accomntant is het geven van oordelen op het gebied wan zijn deskundigheid; 2. Een beperking van de deskundigheid tot financiele verantwoordingen in engere zin zal wellich de functie op den dur ondergraven (oordelen wordt constateren); 3. De aard en de inhoud van de informatiebehoefte in de samerleving kan in zijn algemeenheid worden omschreven als: informatie ten aanzien wan een al of niet optimale samenwerking van de produktiefaktoren (men herinnere zich de eerder opgeroepen spanningsvelden tussen principalen en agenten, $\mathrm{AS}$ ); 4. De "accounting-discipline" kan in zekere mate bijdragen tot de algemene informatiebehoefte; 5 . Indien de deskundigheid van de openbare accountant zich zou uitstrekken tot de "accounting discipline" kan hij in staat geacht worden een oordeel wit te brengen met betrekking tot deze bijdrage van de "accounting discipline"; 6 . De functie van de openbare accountant kan slechts bestaan indien aan een oordeel op het gebied van zijn deskundigheid behoefte is; 7 . Het demonstreren van deskundigheid doet de behoefte concretiseren en lokt het verzoek om een oordeel wit" (Bindenga, 1973, p. 265).

In de eerste voetnoot constateende ik, dat actuele ontwikkelingen rudimentair in Bindenga"s gedachten al voorzien waren. Uit het bovengegeven citaat blijkt dit opnieuw; men herkent duidelijk de commerciele ontwikkelingen in het accountantsveld van de laatste tijd, bijwoorbeeld rond de milieu auditing. Het is jammer, dat de rode draad destijds niet nadrukkelijker is opgepakt; de discussie is op het verkeerde been gezet doordat Bindenga meer dan m.i. nodig en terecht was, de vertrouwenstheorie bekritiseerde. De kritiek van Bak (1975) is in dat licht begrijpelijk, maar de kern van Bindenga's betoog rond de institutionalisering laat Bak helaas liggen ("ik voel mij terzake niet competent tot oordelen", p. 118). Terwijl Bak in die tijd juist - geheel in lijn met de strekking van Bindenga's toekomstperspectief - zijn oratie voorbereidde over "Accountantsverklaringen bij prognoses'! (Bak, 1975b).

Is het derhalve jammer, maar begrijpelijk binnen de beperkingen die Bak zich in zijn reactie stelde, dat Bindenga's poging tot innovatie verdween onder de discussie over de vertrouwenstheorie; bepalld te betreuren is de felheid warmee Groeneveld (Limperg/Groeneveld, 1976) zich tegen Bindenga keert. "In 1973 deed A.J. Bindenga zich als een tegenstander van de vertrouwenstheorie kennen. Hierbij heeft hij zich laten leiden door wat hij zelf sociologische verkenningen 
noemt. Van de sociologen leerde Bindenga ...... Interessante lectur. ongetwijfeld ....... Bindenga omschrijft de functie wan de accountant alls te zjin de gever van oordelen warrvoor behoefte bestaat. De in dit begrip aan het oordelen gegeven toevoeging - "waaraan behoefte bestaat" - is wat rreend, want de accountant zou spoedig geliquideerd zijn waneer hij oordelen zou geven waaraan geen behoefte bestaat ..." (pp. 35, 37) Groeneveld heeft blijkbaar geen antenne voor het meer systematisch denken vanuit de behoeften van de markt, van de samenleving. Het enige watt telt, is het tegen stander zijn van de vertrouwenstheorie, en zoalls gezegd, op dat punt is Bindenga m.i. inderdaad kwetsbaar. Dus kwam er een sternpel op het proefschrift: "non imprimatur", als het ware. En Groeneveld eindigt dus: "Alleen door de vertrowwenstheorie kan het laatste woord worden gesproken" (p. 39). Men vrage zich eens rustig af: waarom zo'n slotzin?

Veel constructiever is de reactie van Frielink (1976). Frielink pakt de informatie-rode draad wan Bindenga op en werkt deze in 1980 uit". "De accountant-controleur moet zich ontwikkelen tot deskundige op het gebied van informatiesystemen en stelsels van inteme controle" (p. 280). En verderop: "De trend die uit de ontwikkeling yalt af te leiden is samen te vatten als het streven naar zelfcontrolerende systemen" (p. 283). In een recent artikel van Kalkman. (1989) over "De accountant van morgen" komen wij boeiende verwachtingen tegen over "real time" controle en "real time" accountantsverklaringen! Nordemann (1984) meent echter dat Frielinks opvattingen in dezen verworpen moeten worden $(p .116)$.

Is het illustratief dat Nordemann verwijst naar het "uitermate belangrijke studierapport "De reikwijdte van de accountantsverklaring" (1978)? Hoe interessant dit rapport ook de gedachten wan voomamelijk accountants heeft gerubriceerd (men zie de literatuurlijst), wat is er gebeurd met de aanbeveling van de commissie: "Aanbevolen wordt door middel van een gericht onderzoek informatie te verkrijgen over de behoeften van het maatschappelijk verkeer" ( $p$. $40)$ ?

Ook Blokdijk (1979) acht de definitie van Bindenga veel te nim, en meent dat de "geheel nieuwe functie" die hij daarin ziet, "niet uit de huidige ontwikkeling is af te leiden "(p. 491).

Nog even terug naar Bak (1975). Bak wil zijn reactje niet beperken tot de wat negatieve discussie over de vertrouwensleer, en draagt drie contouren aan voor de ontwikkeling van een theorie rond de accountantsfunctie. Namelijk:" "De ontwikkeling van de informatieverstrekking door ondernemingen; de ontwikkeling van de 
attestfunctie; de leer van hel gewdkte vertrouwen een radar" (p. 119). Hoezeer de huidige discussies daarom draaien, walt - naast het boven reeds gememoreerde - nog te illustreren met korte citaten wan enkele topmannen uit de internationale accountantspraktijk. "We are in the information service business" (Duane Kullberg, chaiman van Arthur Andersen); het gaat om "an independent opinion business" (John Bullock, chaiman van (thans) Deloitte Europe) (beide ciaten uit "International Accounting Bulletin" van september 1987). En Flint (1988) citeert met grote instemming de opvattingen van Limperg over de vertrouwensrelatie met de samenleving (p. 153 e.a.).

De moraal van deze uit de hand gelopen voetnoot: voomannen in het Nederlandse accountantsberoep hebben regelmatig heldere, $x \mathrm{ij}$ het nog onscherpe, visies gehad op komende onwikkelingen. Maar iedere keer ontstaat een soort collectief afweermechanisme. Er wordt aangetoond dat de vertrouwenstheorie niet zuiver is toegepast, en vervolgens worden badwater en kind radicaal weggedaan. In plaats wan door te gaan met een uruchtbare dialoog en systematisch onderzoek, verwordt het ethos van de vertrouwensleer tot een dogma. Bak (1975) spreekt (m.b.t. Limperg"s visie) van een "wisselwerking tussen behoeften van het maatschappelijk verkeer en de reactie daarop van het accountantsberoep" (p. 116). Maar juist die wisselwerking is niet echt aanwezig; ik meen dat Bak hier net lets te positief leest. Want Limperg schrijft, dat in "tijdruimten van overgang" er onzekerheid ontstaat over de inhoud der functie. En dan? Een wisselwerking? "Evenals steeds zal de accountant in eerste instantie voor zichzelf hebben uit te maken, welk vertrouwen hij opwekt ... sterker beroep op zijn eigen inzicht gedaan ... persoonlijkheid van de accountant zal hier dus een grotere rol spelen ... Niet alleen technisch inzicht bepaalt thans zijn gedragingen ... maar ook andere factoren; met name zijn karakter" (Limperg, 1932/1933, pp. 238/239).

20. De "vertrouwensman van het maatschappelijk verkeer"

In een wat onbekend gebleven artikel uit 1940 heeft Limperg zelf (in een antwoord op Belle, 1940) nog enkele belangrijke kanttekeningen gemaakt bij het begrip "vertrouwensman van het matschappelijk verkeer": "Ik vermoed dat de heer Belle in dit woord de aanwijzing ziel van iemand, die het vertrouwen geniet van her publiek; de accountant zou in die zin iemand zijn, waarin hel publiek bij uitstek vertrouwen stelt ..." (Limperg wijst er dan nadrukkelijk op, dat hij spreekt "van den vertrouwensman VAN het maatschappelijk verkeer" (en niet: IN, zoals Belle schreef), en vervolgt: "De heer Belle moet deze fout onbewust gemaakt hebben 
doordat hij vermeende, dat ik den accountant beschouwde als iemand, die in het maatschappelijk verkeer MEER vertrouwen genoot en verdiende dan andere personen. Dat is geenszins het geval. Hij is de vertrouwensman van het mastschappelik verkeer in de zin van mandataris, een mandataris, voor wie de naam vertrouwensman gekozen is bij wijze van kwalificatie van de aad van het mandaat ( $\mathrm{vgl}$. vertrouwensman van een ondememerscombinatie)". Limperg (1940, p. 6; vgl ook Limperg, 1965, p. $38)$.

Bindenga (1975) schrijft (p. 110): "Het formuleren van de "leer van het gewekte vertrouwen" heeft uitsluitend gediend om de accountant er zich bewust van te laten worden dat een door hem gegeven oordeel over een verantwoording bij derden komt en hij zich daarvan bewast dient te zijn", en verwijst daarbij in een voetnoot naar H.C. Treffers in De Accountant van oktober 1972. Ik meen, dat deze nuanceringen van belang zijn bij de interpretatie van de ook in Limperg (1965) frequent gebruikte termen "accountant-vertrouwensman", "deskundige-vertrouwensman", e.d.

21. Het Leerboek Accountantscontrole (1985) schrijft tenminste onbekommerd: "De accountant fungeert in deze algemene functie, die als meest karakteristieke kan worden beschouwd, dus als vertrouwensman van het maatschappelijk verkeer. Deze functie kan, zoals later uiteen wordt gezet, alleen worden vervuld door openbare accountants" (p. 31). De Lange (1989) schrijft: "Er ontstaat dus een behoefte aan controle, aan waarborgen voor de betrouwbaarheid van de verstrekte gegevens. De concrete taak van de accountant is deze waarborg te verstrekken. De functie van de accountant is dus die van vertrouwensman van het maatschappelijk verkeer" (p. 4) (waarmee ik overigens niet De Lange's stelling wil ondergraven dat accountants moeten samenwerken met EDP-auditors.) (Vergelijkbaar is ook Oonincx en Pruijm, 1987). Het woordje "dus" is mij dus niet duidelijk.

Hoewel Bak (1975), Bindenga (1976) en Blokdijk (1979) op uiteenlopende gronden gepleit hebben voor afschaffing van de term "vertrouwensman van het maatschappelijk verkeer", valt dat dus niet mee. Bindenga (1976) citeert ook nog het "rapport Zahn", "dat vele accountants de theoretische basis van Limperg verouderd achten en als hinderlijk beschouwen bij het verkrijgen van nieuwe, meer bij de tijd passende, beroepsopvattingen" ( $p .323$ ). Rest ons de vraag welke theoretische basis na het rapport van de socioloog Zahn accountants dan wel accepteerden! Of is Flint's (1988) vrees terecht, dat "auditing is what auditors do" (p. 4)? 
22. Vgl. bijvoorbeeld Van Doom (1988), p. 167: "Gemeenschappeljke rek is allereerst het sterk prescriptieve karakter. Men gaat uit van "beginselen"; Taylors Principles of scientific management van 1911 , Mooney"s Principles of organization var 1939 en Kuypers' Beginselen van beleidsontwikkeling van 1980. Het gaal om philosophies, doctrines en foundations; empirische toetsing zal pas later komen, soms zeer veel later. Vooralsnog wordt volstaan met thet ontwouwen van een normatieve logica waruit regels en recepten worden afgeleid. Kembegrip is "doelrationaliteit":" en wat daar verder volgt. Van Doom werd in 1925 in Maastricht geboren.

23. Zie de polemiek, vermeld bij Dijker (1923/1924).

24. Dit onderzoek vindt men beschreven en bediscussieerd in MABnummers uit 1926 en 1927 , in de literatuurlijst nader bij Dijker vermeld.

25. Inductief/deductief; positief/normatief

Limperg (1964), in het bijzonder $A-I$, paragrafen $1 \mathrm{t} / \mathrm{m} 6 ;$ Klant (1980) acht Limperg te behoren tot een "a prioristische traditie" in de geest van Descartes; Groeneveld (1980) bestrijdt Klant en meent dat Limperg's methode zowel inductief als deductief was. Mey (1936): "De leer der accountantscontrole moet dat door analyse en deductie vinden en de praktijk daarin voor elke soort wan opdracht het richtsnoer geven, dat zij in dat geval kan volgen" $(p, 41)$. "Ik gelow, dat het dan beter is en dat de dingen beter tot hun recht komen, als wij deducties opbouwen uit gevallen, die wij allen uit onze ervaring kennen. Hoe moet het zijn, hoe moeten bepaalde gevallen opgelost worden?" (p. 33).

De geciteerde woorden van Mey laten zien, hoe betrekkelijk de begrippen deductief, inductief, normatief zijn. Men heeft dit gevoel nog sterker, als men in Limperg (1964) over de verhouding "Wetenschap en praktijk" leest: "Maar dit betekent niet, dat de wetenschap zich van de praktijk moet afwenden. Het tegendeel is waar: zij moet zo nauw kontakt met de praktijk houden als maar mogelijk is. De theorje moet zich nl. met de praktijk bezighouden als toetssteen voor de juistheid van haar inzichten. Wij kunnen met geen enkele theoretische verklaring genoegen nemen zolang zij niet aan de werkelijkheid is getoetst, d.w.z. zolang niet is aangetoond, dat de praktijk de verklaring van de wetenschap dekt. En omgekeerd moet de praktijk de wetenschap warschuwen indien de langs wetenschappelijke weg gevonden verklaringen afwijken van de werkelijkheid" (p. 22). Wie kan hier nog iets tegen hebben?

Maar als Dijker in concreto vanuit de praktijk waarschuwt in 1927 , krijgt hij toch eigenlijk nul op bet rekest. Als Dijker immers op 
grond wan zijn levensverzekeringsmaatschappijenonderzock en de daarbij afgegeven accountantsverklaringen vraagt: "En wat moeten wij nu?" is Limperg"s antwoord: "Dal is echer niet mijn taxk $U$ dat te zeggen. Dut moeten wij gezamenlijk overleggen ... Het woorbeeld van de heet Dijker bewijst dus niet dat wij achterlik zijn, marar alleen dat dik deel van het onderzoek nog niet rijp is om te worden gecodificeet" (Dijker, 1927, p. 68). Vervolgens krijgt Dijker de schuld, dat hy als nom wil doen accepteren wat in de praktijk bereikt is.

Ik kan dan moellijk anders concluderen dan dat het door Limperg gestelde over theorie en praktijk wel mooi is maar dat in het concrete gesprek over spanningen tussen de theorie over de accountantscontrole en de waargenomen praktijk de theorie niet meer thuis geeft. Maar dan slaat de balans tussen "geloof en wetenschap" (Van Straaten, 1979) toch door naar "geloof".

Het lijkt gepast hier ook nog het omvangrijke werk van Trompert (1988) te noemen, waar men vergelijkbare kritiek aantreft. Alleen moet het mij van het hart, dat het naslaan van de door Trompent gegeven referenties in Limperg's werken mij niet altijd tot dezelfde conclusies brengt als zij Trompert doen.

Wat betreft de hele indeling inductief/deductief, normatief/beschrij]wend etc. noem ik nog Gaffikin (1988). Men kan daaruit concluderen, dat een relevant onderscheid is de toetsingsmethode van theorieën (logisch dan wel empirisch); Limperg nu was een sterk logicus, tegen wie weinigen - if any - opgewassen waren. Dijker toonde meer een empirische inslag, maar het is niet gelukt dat tot serieuze proporties uit te bouwen. Tenslotte vermeld ik nog Gaflikin's insternming met $\mathrm{H}$. Schreuder, dat termen als "positief" en "normatief" zo gevarieerd gebruikt zijn, dat ze "all clarity of meaning" verloren hebben (p. 28).

De moraal (vergelijk noot 19) is uiteindelijk simpel: in het Limpergiaanse spoor komt een wisselwerking, een dialoog tussen theorie en praktijk uiterst moeizaam tot stand. Een grotere openheid voor de buitenwereld lijkt nodig om de vertrouwensrelatic daamee daadwerkelijk te bevorderen.

26. Dijker (1927), p. 20.

27. Zie Dijker (1930); Krom (1988).

28. Waarbij het goed is de eigen relativeringen van Bindenga (1973) te citeren: "Statistisch zal het onderzoek geen araspraak op deugdelijkheid kunnen maken. Enerzijds was de selectieprocedure van de 
beroepsverenigingen niet willekeurig, anderzids werd geen representaieve steekproef uitgevoerd ..." (p.53).

29. Een treffend voorbeeld hiervan lijkt mij de discussie Blokdijk Wilschut (november 1987, en eerder).

30. $\mathrm{Na}$ de somberheden in de voorafgande passages is het goed dit onderzoek (Limperg lostituut, 1987) te cunnen noemen. Tenteer daar dit rapport de bewust door het Limperg Instituat opgenomen handschoen van Frielink is, natar op p. 8 vermeld is. Frielink (1980b) had namelijk geschreven: "IK ga daar thans niet verder op in, maar beperk mij tot de aantekening dat het dringend tijo is dat wij als accountants door middel van empirisch onderzoek vaststellen wat her maatschappelijk verkeer (in al zijn relevante componenten) nu wel of niet begrijpt van onze formuleringen. Al te lang zijn wij bezig met conclusies op basis van wat WII DENKEN dat het maat schappelijk verkeer meent of begrijpt" (p. 717).

31. Maijoor (1989) heeft hierover enige nuttige statistieken verzameld.

32. Het accountantsberoep in liberaliserend Europa

In enige officiele onderzoeksrapporten van de Europese Commissie $(1988 a, b, c)$ wordt wat luchtig gesproken over de integratie-aspekten voor het accountantsberoep; zo word in 1988a onder het hoofd "Importance of barriers to professional business service activities in the EC market" voor de groep "Accountancy, audit etc.". vermeld als "Nature of the most important barriers": "None" (p. 95). En in 1988 b lezen we: "While we did not formally interview representatives in the accountancy profession, it is common knowledge that ..." (p. 18) in alle EG-landen men in principe alle mogelijke diensten kan aanbieden. Uit dit soort rapporten zou een soort niets-aan-dehand sfeer kumnen ontstaan, die miskent dat grote spanningen kunnen gaan optreden in het grensoverschrijdend verkeer ten gevolge van de liberalisatie- en de achtste richtlijn (zie EG, 1984 en 1988d). In werkelijkheid zal het accountantsberoep naar verwachting danig aan de tand worden gevoeld om in een zeer competitieve markt internationaal relevante "value for money" te leveren; vgl. nog Hegarty (1988) en Nordemann (1989). Nordemann heeft zijn gehoor op niet mis te verstane wijze geconfronteerd met de omslag in het "Brusselse" beleid, namelijk van hamonisatie en regulatie naar liberalisatie en deregulatie; en geconcludeerd dat het Europese accountantswezen hard aan de slag moet in de MARKT (citaat van p. 12: "Our profession has traditionally played a leadership role in financial reporting matters, but the danger is that we will be left behind if, by concentrating only on ow own parochial difficulties, 
we fail to delver the solutions the market place cals upon us to provide."

Hoe de accountantsopleidingen in de Lidstaten en daarbuiten nog vergchillen, toon FEE (1988).

33. Zie de tekst wan de adviesaanvraag wan de Statssecretaris in De Accountant, december 1988, pp. 168-170.

34. Dit statement komt op wit de rechtstreekse ervaringen met vele stimulerende clienten (die regelmatig nieuwe uitdagingen bedenken voor de universiteit en zijn bevollking, alsmede de invloed wan vakbladen als "International Accounting Bulletin", "World Accounting Report", "Public Accounting Report", enzovoort.

35. Her "Treadway Report" (1987) is een goede illustratie van de wijze waarop in de Verenigde Staten de ernst van de zaak is ingezien. In Schilder (1987) heb ik getracht wat van deze ontwikkelingen op een rijlje te zetten.

36. Bijv. Abdel-Khalik en Solomon (1988), Gwilliam (1987), Van de Poel (1988), Feenstra (1988), ICAEW Framework (1989), alsmede de overzichtsartikelen van Bedard, (1989), Johnson et al., (1989), Klersey en Mock (1989), en Shanteau (1989).

37. In aanvulling op de in de noot 36 vermelde overzichtsliteraturur worden in deze en volgende noten enige meer specifieke publicaties vermeld, die vanwege de recente verschijningsdatum (meestal) nier in genoemde overzichten zijn vermeld.

Wat betreft de accountantskeuze en -wisseling, en de eventuele variaties in accountantswerklaring: zie bijvoorbeeld Dopuch et al, (1987), Balvers et al. (1988), Craswell (1988), Francis en Wilson (1988), Levinthal en Fichman (1988), Williams (1988), Moizer en Turley (1989). Voor meer specifieke literatuur rond het thema 'onafharkelijkheid', zie Van de Poell en Schilder (1989) en Schilder (1989).

Enige humor is bijvoorbeeld te ontdekken, als men de conclusie van Levinthal en Fichman (1988) - namelijk dat de eerste jaren van de relatie cliènt-accountant zijn te beschouwen als een (kwetsbare) 'honeymoon period'- combineert met een artikel wan Simon en Francis (1988), die vonden dat deze eerste jaren voor accountants vaak duur uitpakken!

Het empirisch onderzoek in ons land van genoemde (en nog te noemen) thema"s wordt vergelijkenderwijs bemoeilijkt door het gebrek aan data-beschikbartheid. Zo konden Moizer en Turley de omvang van de jaarlijkse accountantskosten inbrengen, omdat deze 
in Engeland sinds 1967 gepubliceerd moeten worden in de jaarrekening; te onzent bestat zulk een verplichting niet. In de Verenigde Staten publiceert Public Accounting Report maandeliks "auditor changes" met naam, toenaam en reden; bij ons ligt dit weelal in de besloten sfeer. Craswell vermeld, dat hij in zinn onderzoek verwerkt heeft de jaarrapporten van ondernemingen, die genoteerd waren aan de beurs van Sydney in de periode 1950-1979; dit verschafte hem 28371 rapporten van "industrial companies" en 5151 van 'mining companies'. Wij halen dergelijke aantallen gewoonlijk niet, zodat de te onderzoeken massa's veel kleiner zijn. Doch onze aantallen accountants zijn relatief hoog!

38. Gwilliam (1987b, 1988). Aan de Rijksuniversiteit Limburg verricht R.J.M. Dassen promotieonderzoek naar beroepsaansprakelijkheid claims tegen registeraccountants. De werkgroep VOMAR van het Limperg Institunt heeft verkennende besprekingen gevoerd met verzekeraars over de conclusies, waartoe de ervaringen met zulke claims aanleiding kunnen geven.

39. MacArthur (1988), Maijoor (1989); vgl. ook Nordemann (1989) over de betrokkenheid van het accountantsberoep bij Europese en internationale regelgeving.

40. Definities van "accountantscontrole" en "auditing"

Dit zou een woetnoot zonder einde kumnen zijn; immers, in het begin van paragraaf 5 schreef ik: "Accountantscontrole is dus een functie van de afspraken tussen partijen en de dasraan verbonden onzekerheden." Het gaat bij 'onzekerheden' derbalve over de kern van het vak. Het is dan wel interessant om er op te letten, in hoeverre in de omschrijvingen van 'accountantscontrole' de relatie tussen de partijen (en hun afspraken) en de onzekerheden daarbij behouden blijft. Als ene viterste komen we 'technische' definities tegen, waarbij deze relatie rilet of beperkt benoemd wordt; bijv. Stemheim (1924, p. 1): "Onder accountantscontrole is te verstaan de controle eener administratieve verantwoording door een deskundige, die bevoegd geacht kan worden zich met een dergelijke taak te belasten." Min of meer in deze stijl toch ook wel het Leerboek Accountantscontrole $(1985$, p. 2$)$ : "Accountantscontrole is gericht op het vaststellen van de betrouwbarheid van gegevens.", Woolf (1988, p. 1): "an audit is a process (..) whereby the accounting tecords of a business entity (...) are subjected to scrutiny in such detail as will enable the anditors to form an opinion as to their truth, faimess and accuracy."; Arens en Loebbecke (1988, p. 1): "Auditing is the process by which competent, independent person accumulates and evaluates evidence about quantifiable information 
related to a specific economic entity for the purpose of determining and reporting on the degree of correspondence between the quantifisble information and established criteria."

Aan de andere kant staan omschrijvingen die primair de relatie mssen betrokkenen benoemen; zo bijv. Flint (1988, p. 15): "The social concept of audit is a special kind of examination by a person other than the parties imolved which compares perfomance with expectation and reports the result: if is part of the public and private control mechanism of monitoring and securing accountability. Men herkent hier Limperg's vertrouwenstheorie, die Flint ook met instemming citeert. Daartussenin de in Amerikaanse leerboeken (bijv. Ricchinte, 1988 , p. 4; Taylor en Glezen, 1988, p. 2; Gyy en Alderman, 1987, p. 5; Camichael en Willingham, 1987, p. 3) veel geciteerde definitie uit $1972 / 73$ van de American Accounting Association: "Auditing is a systematic process of objectively obtaining and evaluating evidence regarding assertions about economic actions and events 10 ascertain the degree of correspondence between those assertions and established criteria and communicating the results to interested users." (Vooral het stukje na "regarding" geeft enige nuance). Vergelijk ook de omschrijving van C.W. Schandl uit 1978 (geciteerd in Abdel-Khalik en Solomom, 1988, p. 96): "Aluditing is at human evaluation process to extablish the adherence to certain norms, resulting in an opinion (judgment) ${ }^{*}$. Ook Achilles en, Bijleveld (1986) en Oonincx en Pruijm (1987) hebben elementen van beide. Wolnizer (1987) trekt een parallel met kwaliteitscontroles door tabrikanten teneinde het consumentenvertrouwen te winnen.

En laat ik mij haasten daaraan toe te voegen, dat ook in het Leerboek Accountantscontrole, Woolf, enzovoort allerlei nuanceringen voorkomen, de relatie met het maatschappelijk verkeer wordt behandeld en de rol van de "gebruiker" belicht.

Toch acht ik de accenten niet van onbelang. Immers, hoe nadrukkelijker "auditing" wordt onderkend en onderwezen als functie van relaties tussen derden, hoe geringer de kans op vaktechnische en intern georiënteerde isolatie. In die zin was Bindenga's toevoeging. "waaraan behoefte bestaat" (zie verder noot 19) bepaald geen luxueus pleonasme.

41. Van 26-28 september 1988 organiseerde het NIwRA een drukbezochte conferentie "Using expert systems by accountants/ auditors"; de conferentiedocumentatie bevat diverse overzichtsartikelen (0.a. White, 1988, en Chandler, 1988), alsmede interessante voorbeelden van ontwikkelde expertsystems.

Welhaast klassiek is het antikel van Steinbart (1987). Ook de reviews van Connell (1987) en Abdolnohammadi (1987) bieden een 
bruikbaar beeld van het groeiend aanal expertsystemen voor de accountant.

Men behoef van deze expertsystemen geen wonderen te verwachten, aangezien de daarin verwerkte expertise afkomstig is van accountants, die evenmin wonderen verrichten. Maar een gesprek met "een intelligente collega" (zalls G.G.M. Bak eans zei) is wel bereikbaar.

42. Onderwijsvemieuwing

Boshwizen's laatste paragraaf "Implicaties voor het medisch onderwijs" kan ook door accountants met rode oortjes gelezen worden. Zij merkt daarin op, dat een zorgvuldige afstemming tussen kemnisverwerving en praktijktowpassing van groot belang is, en beschrift in dit verband onderwigsmethoden, bekend als "cognitive apprenticeship". Het zijn gedachten die juist in een accountantsopleiding vanwege de nawwe relatie theorie-praktijk heel relevant zijn, en goed kunnen aanshiten op denkrichtingen binmen het NIVRA inzake onderwijsontwikkeling. (In de NIVRA studiegids $89 / 90$ lezen we: "Voor het verwullen van de accountantsfunctie is naast kennis omtrent systemen, methoden en technieken de vaardigheid nodig om problemen op wetenschappelijk verantwoorde wijze aan te pakken. Het aanderen van regels en voorschriften is daarom ondergeschikt aan het verkrijgen van vaardigheid in het toepassen van wetenschappelijke methoden." Uit constructieve besprekingen met vertegenwoordigers van het Onderwijsbureau van het NWRA is ons gebleken, dat genoemd citat het NIvRA emst is; dientengevolge bestaat serieuze interesse om over een bijstelling van de accountantsopleiding mee te denken). Waar Boshuizen's laatste woorden zijn: "Veel van deze oefeningen lenen zich uitstekend voor een computerondersteunde aanbiedingswijze" (p. 152), ziet men zowel de goede synergiemogelijkheden met onze interesse voor de ontwikkeling van expertsystemen als het toch wat schrille contrast met de huidige monotone vraagstukkentoetsing. Deze vraagstukken zijn weliswaar in oorsprong gebaseerd op praktijksimaties, doch bij hun concipiëring ontdaan van alle intermenselijke spanningsvelden. Waar in de praktijk voortdurende feed-back vatuit cliènt, auditteam en vaktechnische ondersteuning plaatsvind, bestat de schriftelijke toetsing uil vier maal drie uur snelschrijven op grond van een gegeven casus.

Bij enkele onderwijsexperimenten hebben wij als docenten wel eens de rol gespeeld van de client in de casus; de cliënt wil dan een concrete offerte gepresenteerd hebben, die enerzijds zaken als risicoanalyse en vaktechniek rechtoet, doch anderzijds ook "walue for money" en een goede relatie levert. Howwel de indrukken over kwaliteit en diepgang van de presentaties door studenten bepaald 
positief warer, moesten deze exporimenten in aantal beperkt bliven wanwege de stricte examenvoorbereiding.

In samenwerking met genoemde vakgroep onderwijsontwikkelingen onderwijsresearch en het NIVRA hopen wij het komende studiejaar meer gestructureerd onderwijsaltematieven te beproeven.

43. Theologen en psychiaters

Wat betreft de theologen denk ik hier aan het fenomeen van de Klinische Pastorale Vorming (K.P.V.) en de empirische theologie van Van der Ven. Deze wetenschap dank ik aan de pastoraalpsycholoog drs. S.W.R. Polman.

Wat betreft de K.P.V. citeer ik wit een lezing van Roscam Abbing (1988): "In de K.P.V. gaat het om leren communiceren door zelf te ontdeklen waar je in de communicatie faalt... De opgaaf is om de eigen wijze van communiceren, qua vaardigheid en qua inhoud op de proef te stellen in gesprekken met bewoners en patienten, verzorgers en verplegenden, collegae-deelnemers aan de cursus...Het kernwoord...is feedback... Over de mens kan alleen in concrete verhoudingen gesproken worden (de contekstualiteit). De deelnemer leert zichzelf vergtaan als mens-in-betrekining, als relationeel mens." Juist voor pastores luistert het bijzonder nauw orn goed om te gaan met het mengsel van kennis, ervaring en herinnering in een concrete relatie; openheid voor de uniekheid die elke ontmoeting in zich dratagt.

Van der Ven (1986) wil daarom in plaats van speculatieve theologische reflectie over de $z$ in en onzin van het menselijk lijden, komen tot 'empirisch-theologische' hypothesevorming betreffende de theodiceeproblematiek. De uitgangsvraag luidt: "wat gaat er in gelovigen eigenlijk om, wanneer zij met lijden worden geconfronteerd?" En: "vălt er in de betekenissen die zij aan dit lijden geven een ontwikkeling aan te wijzen?" (p. 189). En hij concludeert aan het slot: $\mathrm{Op}$ basis van aldus verkregen beschrijvende em verklarende kennis zijn een systematische diagnostiek en adequate zorg-en hulpverlening mogelijk." (p. 206), Die laatste zin zall dan zowel medici als accountants weer vertrouwd in de oren kunnen klinken; wellicht moet voor accountants 'diagnostiek' en 'zorg- en hulpverlening' duidelijkheidshalve vertaald worden in termen als "bedrijfsstudie" en "risicoanalyse" alsmede "cliëntbediening" en 'controleplan". Maar de rode draad blijft: systematisch onderzoeken van en het openstaan voor de vele relatieaspecten, die eigen zijn aan het fungeren tussen vele partijen.

Wat betreft de psychiaters attendeer ik op het eerder genoemde werk van Kabela. Hij beschrijft, welke moeilijke, onzekere en subjectieve 


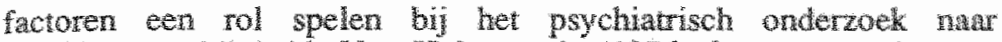
"ubetsongeschiktheid. Van Hulsenton"s (1976) faneuze aratie ove "Subjectieve aspecten wan accountantscontrole" kan hist gerust uan de medici worden angeboder.

In een bespreking wan het proefschrift van Kabela van de hand van Koerselman (1989) (met dank an mevrouw Lies Schlder). concludear deze" "Het onderzoek bevestigt her vemoeden dat psychiaters dezelde feiten beropshalve zeer verschilend interpteteren. Aan het werkelyke problem wan de psychiatre, het ontbreken van consensus over adaptatie- en pathogenesewagagnikken, gaat het boek echter voorbil". Met woord "consensus" is ook in accountantskringen goed bekend, zodat wil toe zin aan de volgende voetnoot.

44. Professional jugment

Zie voemoot 36 voor televante overzichtsheratur, alsmede: Van de Poel en Vaassen (1988). De vier in noot 36 genoemde overzichtsartikelen wit AOS (Accounting, Organizations and Society) (1989) hebben als rode draad eer wij grote censgezindheid over de beperkte resultaten van de 'behavorial audithg research" (BAR) en de hogere verwachtingen van de cognitieve tesearch. Uit de BAR is weliswar meer inzicht ontstan in het gedrag en het proces van oordeels- en besluitvorming door accountants; maar het darut nog miet goed te concluderen wat nu de experts onder hen onderscheidt van de "jonkies" ("novices"). Mar de cognitieve benadering levert wat dat betreft meer op, en ligk zichbad te maken dat de experts zich onderscheiden door een hoogwazdiger kennis en en betere organisatie en toegankelijheid van die kenuis; dit markt hen tot efficiente probleemoplossers.

Zowel voor de beroepspraktik als voor de opleiding 2 in dit belang rijke stappen, die kunner helpen bij het ontwikkelen van hulpmiddelen als expertsystems en trainingen. De relate met noot 41 (expertsystems) en 42 (samenwerking met verwante researchers) is dudelijk. Het is trowwens opvallend, hoe vak de medici worden genoend in de hier an de orde zijnde literanur?

Het voert hier werkelijk te ver on intussen ook nog relevante deehesultaten te noemen. Die zijn er echer wel. Ze liggen vooral in het aangeven van specifieke vatarigheden c.q. het bliken te ontbreken van verwachte eigenschappen. 20 is het nutrig, dat geconstateerd wordt warin accountants wich NLT duidelijk onderscheiden van "gemiddelde" mensen, bijw. de gevoeligheid voor beinvloeding ("biases"), de beinvloedbaarheid door ervaringen wit het verleden of niet bij voorbaal relevante ovenenkomaten met andere gevallen, de behoefte aan een wootopig (?) vertrekpun, het niet 
bjzonder thü zijn in warschinlijkheidsberekeningen of statistiek; kortom, de nomalk menselijke beperkingen en subjectiviteiten. Er was wat dat betreft enigsins een mythevorming rond accouriants, en dat kan maar beter weg zijn. Ook is het goed dat accountants zich deze beperkingen terdege bewust zijn.

Madar dan is het ook wel weer leuk, als Ashton en Ashton (1988) schrijven dat hun gebleken is dat accountants meer dan "persons in general" ontvankeljk zijn voor nieuwe informatie, juist ook als ze daardoor eerdere conclusies moeten herien. 20 is er ook een aardig experiment van Wright (1988), die een controleprogramma liet opstellen vanuit drie verschillende vertrekpunten de complete dossiers van vorig jaar, en samenvatting daaruit, of alleen recente informatie. Zijn conclusie was, dat het werken met een samenvatting tot een hoge effectiviteit EN efficiency leidde.

45. In het bijzonder denk ik hier aan Feenstra (1988), o.a. pp. 20 e.w., en Van de Poel (1988), pp. 19,27 vv, en voetnoot 60.

46. Het contextmaspect wordt o.a. behandeld door Johnson et al. (1989). In Hofstede (1987) worden de context-studies eveneens kort maar zeer krachtig bepleit.

\section{Researchmethodes}

Welke research-methodes zich hierwoor het best lenen, staat nog nader te bezien. Er is nog wel eens kritiek op het realiteitsgehalte van uitgevoerde research; bijv. Shanteau (1989), p. 169: "This difficulty in devising appropriate task examples suggests that heuristics and biases may have limited applicability in real-world auditing contexts".; Klersey en Mock (1989, p. 137): "However, it is important to conduct research in audit decision-making in settings matching, as nearly as possible, actual audit contexts since laboratory settings tend to dilute the generalizability and practical application of the study".

Over de relevantie van laboratoriumexperimenten wordt echter niet eenduidig gedacht. Houghton en Robinson (1987) melden een laboratorium-onderzoek, waarvan de conclusies identiek waren aan die van een eerder uitgevoerde veldstudie. Mckinnon (1988) acht veldonderzoek van groter belang en behandelt enige gewenste "strategies and tactics" om de geloofwardigheid en betrouwbarheld van veldonderzoek te vergroten. Chow et al. besluiten hun bijdrage in Abdel-Khalik en Solomon (1988) met een breed spectrum." "In exploring multi-methods, in-depth case studies, surveys, interviews. archival research, lab studies (including experimental economics), analytical work, and empirical analysis using large data bases, all are likely to contribute to our understanding of the environment of 
auditirng and key dimensions of the components of demand and supply. While each research approach has its strenghts and weaknesses (..). together they can provide a picrure of trerds and systematic behaviour which will prove to be of use to decision makersauditors, companies" managers and employees, participants in the market as suppliers, customers, and prowiders of extemal financing, and regulators charged with the responsibility to set policy". (p. 183).

47. Hierbij zal er tevens rekening mee moeten worden gehouden, dat cultuur, structurur en controlebenadering binnen de grote nccountantskantoren aanzienlijk kunnen werschillen. Wat betreft de culuur hebben Soeters en Schreuder (1986) een interessant onderzoek verrichi. Inzake structur en controlebenadering is door Cushing en Loebbecke respectieveligk Kinney in 1986 een onderscheid aangebracht in kantoren, waarvan de controlebenadering meer of minder gestructureerd is; wat betreft de Big Eight kantoren was de indeling: "structured" (Deloitte, Haskins \& Sells, Peat Marwick Mitchell \& Co, Touche Ross); "intermediate" (Arthur Andersen, Arthur Young, Ernst \& Whinney); 'unstructured' (Coopers \& Lybrand, Price Waterhouse). De in mei 1989 aangekondigde fusie tussen Arthu Young en Ernst Whinney is dus tussen twee 'intermediate' firms. Onderzoeken van Williams en Dirsmith (1988), Morris en Nichols (1988) en Bamber en Snowball (1988) gaan nader op dit onderscheid in.

48. Bijvoorbeeld Ashton (1984), die 15 cases over oordeels- en beshitvorming voor het onderwijs publiceerde. De casus Najaarsconferentie NIvRA 1988 (zie Groeneveld, 1989 en Van de Poel en Schilder, 1989) is inmiddels ook op enkele universiteiten gebruikt. Ook binnen de werkgroep VOMAR van het Limperg Instituut is onderzoeksmateriaal ontwikkeld, dat voor het onderwijs te gebruiken is (publikatie vemoedelijk rond de jaarwisseling $89 / 90)$.

49. De accountantsverklaring bij Philips

In het MAB van december 1934, januari 1935 en april 1939 heeft Limperg hierover geschreven, omdat in diverse Engelse bladen over de lange verklaring van Accountantskantoor P. Klijnveld gematigd positief werd bericht (de lengte werd vooral veroorzaakt door bij de meeste balansposten een kort controlecommentaar te geven). Vooral in het latstgenoemde artikel betoogt Limperg breeduit, dat deze lange verklaring overbodig en schadelijk is. De mogelijke interesse van de cliënt komt nuet aan bod. "De verklaring zal dus haar doel te beter dienen naarmate ze stelliger is en minder te denken geeft, 
nadrmate ze voor de laek gemakkelijker te begrijpen ist" En Limperg besluit: "Het zou een winst zijn voor het vak, indien in de toekomst het verslag van Phulips en de verklaring wan zijn accountant den Nederlandsen accountant ten voorbeeld zou kunen worden gesteld." In de oorlogsjaren was de Philips-zetel verplaatst naar Willemstad, Curaça. Het daar uitgebracht verslag was beperkt tot het "niet-vijandelijke gebied". De mogelijkheid wot accountantscontrole ontbrak voor een zeer belangrijk deel, er was dan ook geen accountantsverklaring opgenomen. In het weer in Eindhowen opgestelde verslag over $1944 / 45$ werschijnt dan opeens een "korte" verklaring. (Informatie op gezag van H.L. Brink).

50. Bijvoorbeeld Bak (1986, p. 253): "Het is te betreuren dat het maatschappelijk klimaat rond ondememingen nauwelijks toelaat dat legitieme verschillen van opvatting tussen accountant en cliënt omtrent de interpretatie van relevante voorschriften via de accountantsverklaring in de openbaarheid worden gebracht". Frielink (1986, p. 256) pleit voor empirisch onderzoek "om te toetsen of andere bewoordingen, weglatingen of toevoegingen de duidelijkheid vergroten". Schoonderbeek (1986) stelt in dit verband voor "gestructureerd overleg met representanten van het maatschappelijk verkeer" (p. 17). Ophof (1988, p. 298), Bak (1989) en Bindenga (1989) bepleiten onder meer een verwijzing naar de gehanteerde waarderingsgrondslagen. Op het moment wan schrijven van deze tekst is nog steeds niet een rappont van de NIvRA-commissie "Herziening Verklaringen" verschenen; doch sterke geruchten doen de ronde, dat er meer ruimte voorgesteld zal worden voor mances in de accountantsverkllaring.

51. Deze gedachte herken ik in de gewijzigde tekst van de accountantsverklaring in de Verenigde Staten: "Those (generally accepted auditing) standards require that we plan and perform the audit to obtain reasonable assurance about whether the financial statements are free of material misstatement." (AlCPA Statement on Auditing Standards 58, April 1988).

52. Waarbij ik aanteken dat de warschuwing van Van der Geest (1989), in een bespreking van het afscheidscollege van Th. A. Stevers, mij niet ontgaan is: "Afscheidsredes van terugtredende hoogleraren zijn vaak boeiende lectuur. Boeiender meestal dan de openbare lessen waamee hun pas benoemde collegae het wetenschappelijke podium betreden. De laatste staan vol "niewwe richtingen", "veelbelovende ontwikkelingen" en "boeiende ondarzoeksterteinen" die de noviet zal betreden. De nieuweling heeft er duidelijk zin in....". Ik geef dat ruiterlijk toe. 
53. Wetenschappers en practici

Het likt van realiteitszin te genugen on te constateren dat ar ange afstand is te overbruggen tussen het wetenschappelijk ondtarzoek van accountants(controle) en de praktiserende accountants. Flint (1988b) constateert nuchter, dat dat bestaat in alle kenuisgebieden die prakische toepassing krijgen. Maar, voegt hij eraan toe, anders dan bij bijwoorbeeld medicijnen: "Accounting and auditing have no comparable track record." Accountants zijn geworden wat zij zijn door een kritische instelling, en zij zullen dus pas research resultaten accepteren, als deze voldoende onderbouwd en geloofwatardig zijn. Aan de andere kant, zegt Flint (met en verwijzing naar Zeff): nu deze research snel opgekomen is, moet zij ook wel strak en principieel zijn om ook serieuze wetenschap te worden. Er is dus begrip en respect van twee kanten nodig.

Bull (1987) maakte in de Verenigde Staten in 1982 (op 58-jarige leeftijd) de overstap van partner in een accountantskantoor naar wetenschapper. "I wanted to understand why the academic and the practice worlds of accounting had drifted $\$ 0$ far apart..Math and statistics were the most difficult for me, and even now I barely possess the minimum skills needed in those subjects." (p. 85). En meer inhoudelijk over het verschil in benadering tussen de practicus en de wetenschapper: "Practicing accountants generally want answers to relevant, but broad, questions. Such questions are hard to define in terms of cogent theory involving variables subject to empirical observation. Academic research, on the other hand, discourages research on questions for which no empirical evidence can be found." (p. 88). En hij besluit met een oproep tot "contiruous dialogue" tussen "academic and practicing accountants." (p. 90).

Greene (1984) beschrijt een samenwerkingsworm tussen practiserende accountants en wetenschappers. Ashton (1983) gaat aan het eind van zijn monografie nadrukkelijk in op deze relatie. Enerzijds beschrijft hij het 'partnership', dat zijn research mogelijk maakte. Anderzijds wijist hij op de mogelijke conflicten, zoals het verschil in de doelstellingen van wetenschappers en practici en de consequenties van eventuele woor het accountantsberoep kritische vitkomsten. "Mutual respect and cooperation" zal nodig zijn (p. 55).

Het zou niet moeilijk zijn om vergelijkbare voorbeelden uit anverwante gebieden te vinden (denk slechts an de pittige afscheidsrede van Stevers, 1989). De moraal bij Flint (19886): "Progress may be slow because of the intellectual defensiveness of the profession, but there is room for hope that attitudes will change." (p. 30). 
Deze hoop werd te onzent bevestigd, doordat het accountantskantoor Bakker, Versteegh en Co. twee zijner assistenten (Dassen en Vaassen) in de gelegenheid stelde aan de RL promotieonderzok te verrichten.

Tenslotte refereer ik nog aan Bohannon en Lewau (1988), die voor de fysiotherapie aanbevelingen doèn om de afstand tussen wetenschappelijk onderzoek en praktijk te verkleinen; bijw. door studenten erop te trainen dat zij onderzoeksresultaten toepassen, en door onderzoeksverslagen voor cen breder publiek (samengevat) toegankelijk te maken.

54. Interventiewetenschap en kundes

Van Doorn (1988) heeft zoveel boeiende analyses bijeengebracht dat kort citeren uit dit complex nauwelijks mogelijk is. Hij beschrijft hoe de beheersing wan onze samenleving is toegenomen hand in hand met voortgaande rationalisering. In dat proces is een "sociale technologie' ontstaan tussen sociale wetenschappen en sociale werkelijkheid. Deze technologie leidt tot 'interventie', tot bewust en gericht ingrijpen in de maatschappelijke werkelijkheid. Vandaar: "Onder interventiewetenschappen verstaan we de speciale disciplines - soms 'kundes' genoemd - die bepaalde wijzen van interventie (bijvoorbeeld organiseren) of interventie op bepaalde terreinen (bijvoorbeeld onderwijs) systematisch bestuderen teneinde te komen tot het ontwikkelen van praktijkgerichte handelingsmodellen en -methoden" (p. XII).

Van Doorn schetst, hoe met name in de negentiende eeuw "het grote moderne interventieprogramma' is opgekomen; interventie namelijk door bestrijding van individueel menselijke noden (het professionalisme van de medici), door een efficiënte organisatie van de materiële productie (het ingenieursdenken, de 'engineering") en door de verwetenschappelijking van het staatsbestuur. Met name binnen de 'engineering' vinden we dan de 'kunde"-vakken (organisatiekunde, bedrijfskunde, management science) (pp. 159 vv.). Men zal in deze sfeer ook de accountancy herkennen (administratieve organisatie, controleleer) als bijdrage aan de 'organisatie van materiële produktie'.

Nog enkele toevoegingen: "De bemoeienis van de organisatie- en beleidswetenschap met de maatschappelijke werkelijkheid kan worden gekarakteriseerd als het scheppen wan orde in een onordelijke werkelijkheid; als werktuig fungeert de wetenschap." (p. 182). De monitor-functie van de accountant draagt bij aan dit orde scheppen, althans aan het terugdringen van onordelijkheid (herinner U de parabel van de heer en de knechten). En op p. 186: "In de eerste plaats lijken de beleidsanalyse en de organisatieleer, in hun 
instrumentaliteit, geroepen diegenen van dienst te zijn die zelf doende zijn met organiseren en beleidvoeren. Bij gebrek alan beter zou kunnen worden gesproken van "actorwetenschappen". Tot deze klasse van wetenschappen behoren de vele -kundes: bedrijfskunde en bestuurskunde, onderwijskunde, informatica, krijgskunde en wellicht ook het positieve recht. Zij verschaffen aan de handelende mens een apparaat om in een bepaald "bestel" ....doelmatig werkzaam te zijn."

Dat het hierboven genoemde medisch-professionalisme benamingen kent als (huisarts)geneeskunde, geestelijke gezondheidskunde, lijkt mij hier goed bij aan te sluiten.

In het laatste hoofdstuk "Wetenschap, rede en macht" geeft Van Doorn dan nog enkele typeringen van deze tak wan wetenschap. "De formule biedt de mogelijkheid tot verbinding van theorie en praktijk, van reflectie en interventie. Zij dwingt wellhast tot samenwerking tussen de thans gescheiden sociale wetenschappen en tot contactleggen met filosofie en ethiek, zonder welke de fundamentele vraagstukken uit de programma's niet kunnen worden begrepen en verwerkt" (p. 195). Sociale wetenschappen zijn de "geestelijke vorm waarin onze samenleving zich rekenschap geeft wan haar bestaan" (p. 191). Op p. 194 staan criteria en voorwatrden.

Het laatste woord over deze mogelijke inkwartiering wan accountancy bij de interventiewetenschappen is bepaald nog niet gezegd. Wat mij erin aanspreekt, is de plaats in de historie, de aansluiting bij de 'kundes', de analyse van de bijdrage aan de beheersing van en orde in de samenleving, de werbinding theorie en praktijk, de dialoog met andere takken van wetenschap.

55. Na de vorige voetnoot zal de voorliefde voor "kunde" duidelijk zijn. Het begrip "leer" heeft althans vandaag voor mij associaties met dogma's, vaststaande theorie, gegeven wijsheden. Ik mis de dialoog, de wisselwerking met de praktijk en het onderzoek, de functie in de samenleving. Bovendien is "leer van de accountantscontrole" nogal object-gericht. In "accountantskunde" klinkt meer door, dat her gaat over de functie van personen in hun praktisch handelen, temidden van anderen- maar tevens om de systematische bestudering daarvan. Dat lijkt mij overigens goed aan te sluiten bij de kern van de vertrouwenstheorie van Limperg; ik heb de indruk dat "leer" destijds niet de wat pretentieuze associaties had, die ik er nu in proef, doch eerder het regendeel ("kunstleer" was op zichzelf nog geen wetenschap, Limperg, 1964, p. 25).

56. Knottnerus (1988), pp. 6 vv. 
57. Van de Poel en Schilder (1989); Groeneveld (1989), p. 458.

58. Een dergelijke bereidheid bleek ook in Soeters en Schreuder (1986).

59. Zje ICAEW (1989).

In "Accountancy Age" van 9 maart 1989 licht Malcolm Cooper toe, hoe de Research Board van het Engelse Accountants Instituut onderzoek initieert, sponsort en coördineert tussen afzonderlijke onderzoeksinstituten.

60. Bijvoorbeeld "Ondernemingsvormen en verslaglegging in Europa", een project van de Erasmus Universiteit Rotterdam. De "world-wide" audit krijgt geleidelijk ook meer aandacht in vakpublikaties; zie bijvoorbeeld Zacchea (1988), Haskins en Williams (1988), De Heer en Van Manen (1988). Dit alles uiteraard naast de professionele voorschriften vanuit IFAC, IASC e.d. en het reguliere beroepsnieuws.

61. In april 1989 werd in een gezamenlijke publikatie van de voorzitters van de 'Big Eight' accountantskantoren gepleit yoor cen heroriëntatie in de accountartsstudie (Perspectives, 1989). De universitaire opleiding zou zich meer moeten richten op vaardigheden dan 'weetjes', "the focus should be on developing analytical and conceptual thinking - versus memorizing rapidly expanding professional standards" (p. 8). En (vgl. noot 53): "Innovative methods to increase interaction between the practitioners and the professoriate must be created" (p. 13).

Contact tussen Nederland en elders hoeft dus geenszins eenzijdig te zijn; wij hebben ook zeker wat te exporteren! Misschien lezen we dan nog weer eens ergens: "Had the Englisch-speaking accountants been aware of earlier debates in Holland, our literature would have been greatly enriched and one suspects, much smaller!" (R.K. Ashton, geciteerd bij Radebaugh, 1983).

62. Frielink (1977). Als laatste en symbolische verwijzing noem ik Shanteau en Peters (1989). Zij pleiten voor meer aandacht voor eigenschappen als 'Creativity, Confiderce and Communication' bij accountants, omdat deze huns inziens "are major components of 'the right stuff' in accounting" (p. 10).

63. Inzake deze tekst uit de eerste brief van Paulus aan de gemeente in Thessaloniki (hoofdstuk 5:21) beperk ik mij tot het volgende. "Onderzoekt" is een vertaling van het Griekse "dokimazete"; het is ook wel vertaald met "beproeft", "toetst" (Latijn: probate; Duits: prifet!). Het gaat dus niet om vrijblijwend, wereldvreemd, "theoretisch" onderzoek - maar om betrokken, geëngageerd, kritisch onder- 
zoeken. En wel: gericht op een doel: het behouden van het daain aangetroffen goede. Het lijkt mij een goed motto, zowel voor het wetenschappelijk onderzoek van accountantscontrole - als woor het controlerend onderzoek, de "Prifung" door practiserende accountants. 


\section{LITERATUUR}

Abdel-Kahli, A.R., I. Solomon (eds.), Research Opportunities in Auditing: The second decade, 1988.

Abdolmohammadi, M.J., Decision and Expert Systems in Auditing: A Revew and Research Directions, in: Accounting and Business Resiearch, Spring 1987, pp. 173-185.

Achilles, S.L., H. Bijleveld, Inleiding tot de accountantscontrole, 1986.

Arens, A.A., J.K. Loebbecke, Auditing, an integrated approach, 1988.

Ashton, A.H. R.H. Ashton, Sequential Belief Revision in Auditing, in: The Accounting Review, October 1988, pp. 623-641.

Ashton, R.H., Research in audit decision making: rationale evidence, and implications, 1983.

Ashton, R.H., Integrating Research and Teaching in Auditing: Fifteen Cases on Judgment and Decision Making, in: The Accounting Review, January 1984, pp. 78-97.

Audit Plus, Van Dien + Co Accountants, lid van Deloitte Haskins + Sells International, 1988.

Bac, A.D. Overheidsaccountancy, bijzonder genoeg, oratie 7 april 1989, Katholieke Universiteit Brabant.

Bak, G.G.M., De accountantsfunctie in de maatschappij (2), in." Maandblad voor Accountancy en Bedrijfshuishoudkunde, maart 1975, pp. 115-122.

Bak, G.G.M., Accountantsverklaringen bij prognoses, oratie 18 juni 1975 , Katholieke Hogeschool Tilburg, $1975 \mathrm{~b}$.

Bak, G.Gi.M., Controle en advies: de rol van de controlerend accountant bij het tot stand komen van de jaarrekening, in: Maatschappelijke Berichtgeving (afscheidsbundel J.W. Schoonderbeek; red. J. Klaassen et al.), 1986, pp. 243-253.

Bak, G.G.M., Accountantsverklaring, de pretentie van de accountant, in: Het Financieele Dagblad, 2 mei 1989. 
Balvers, R.J., B. Mc Donald, R.E. Miller, Underpricing of New Issues and the Choice of Auditor as a Signal of Investment Banker Reputation, in: The Accounting Review, October 1988, pp. 605-622.

Bamber, E.M., D. Snowball, An Experimental Study of the Effects of Audit Structure in Uncertain Task Environments, in: The Accounting Review, Jully 1988 , pp. 490-504.

Bedard, J., Expertise in Auditing: Myth or Reality?, in: Accounting, Organizations and Society, Vol. 14, Nos. 1/2, 1989, pp. 113-131.

Belle, L.H., Grondslagen der Accountancy, 1931/1961.

Belle, L.H., Accountancy en Beroepsethiek, in: Maandblad voor Accountancy en Bedrijfshuishoudkunde, januari 1940, pp. 2-4.

Bijbel, Groot Nieuws, 1984.

Bindenga, A.J., Het vrije beroep van accountant, 1973.

Bindenga, A.J., De accountantsfunctie in de maatschappij, in: Maandblad voor Accountancy en Bedrijfshuishoudkunde, maart 1975, pp. 102-114.

Bindenga, AJ., Antwoord aan prof. Frielink, in: De Accountant, februari 1976 , pp. 322/23.

Bindenga, A.J., De betekenis van de accountantswerklaring in de externe verslaggeving, in: Dorsman en Huizing, 1989, pp. $60 \mathrm{t} / \mathrm{m} 72$.

Blokdijk, J.H., De maatschappelijke rol van de accountant, in: Maandblad voor Accountancy en Bedrijfshuishoudkunde, november 1979, pp. 482496.

Blokdijk, J.H., De verwachtingskloof en het (on)begrip verantwoording, in: De Accountant, november 1987, pp. 102-106.

Bohannon, R.W., B.F. Levau, Het gebruik van onderzoeksresultaten door degenen die klinisch werkzaam zijn: een literatuuroverzicht voor fysiotherapeuten, in: Stimulus, 1988-1, pp. 1-9.

Boshuizen, H.P.A., De ontwikkeling van medische expertise, 1989.

Bouma, J.L., De markt voor vennootschappelijk bestuur, 3 dellen, in: Maandblad voor Bedrijfsadministratie en Organisatie, september $t / m$ november 1988. 
Buisman, J.H. R.L. van Marion, Miliew en Accountart, in: De Accountant, april 1989, pp. 366-372.

Bull, I. A Transition from The Profession To Academia, in: Accounting Horizons, September 1987, Pp. $85 \times 91$.

Carmichael, D.R., J.J. Willingham, Auditing Concepts and Methods, 1987.

Center for Intemational Accounting Development, Accounting and Auditing in the People's Republic of China, 1987.

Chandler, J.S., Expert Systems in Auditing: Lessons from the Eighties for the Nineties, in: MIvRA, 1988.

Code of Professional Conduct of the American Institute of Certified Public Accountants, 1988.

Commission of the European Communities, European Economy, 1988 a.

Commission of the European Communities, Research on the 'Cost of nonEurope", Basic Findings, Vol. 1, 1988 b.

Commission of the European Communities, Research on the 'Cost of nonEurope', Basic Findings, Vol. 7, $1988 \mathrm{c}$.

Connell, N.A.D., Expert Systems in Accountancy: A Review of Some Recent Applications, in: Accounting and Business Research, Vol. 17, No. 67, 1987, pp. 221-233.

Craswell ${ }_{n}$ A.T., The Association Between Qualified Opinions and Auditor Switches, in: Accounting and Business Research, Vol. 19, No. 73, 1988, pp. 23-31.

Cushing, B.E., J.K. Loebbecke, Comparison of Audit Methodologies of Large Accounting Firms, 1986.

Dassen, R.J.M., De Leer wan het Gewekte Vertrouwen: Agency avant lat lettre?, manuscript ingediend voor publikatie, 1989.

Dijker, R.A., De verantwoordellijkheid van den accountant, alsmede daarop volgend debat met A. Schilder, in: Accountancy, april 1923, pp. 50-52; october 1923, pp. 132-134; Maandblad voor Accountancy en Bedrifshuishoudkunde, maart 1924, pp. 57-59; september 1924, pp. 146-149. 
Dijker, R.A., De onderteekening van de balansen wan levensverzekering maatschappijen, in verband met de berekening van het bedrag der loopende verplichtingen, in: Maandblad voor Accountancy en Bedrijehuishoudkunde, september 1926, pp. 113-117; alsmede 'Naschrift' (na reacties van De Blaey, de Goey, Keuzenkamp en Sternheim) in Maandblad voor Accountancy en Bedrijfshuishoudkunde, april 1927, pp. 57-62.

Dijker "R.A., Het begrip der 'natuurlijke' beperking bij de accountantscontrole en de invloed daarvan op de accountantsverklaring, (stellingen, inleiding en debat), 1927.

Dijker, R.A., De 'publieke" en de 'private' taak van de accountant, 1930 (opgenomen in: Vijftig jaar MAB, deel 2, 1974, pp. 205-221).

Doom, J.A.A. van, Rede en Macht, 1988 ('1989' wordt vermeld bij de copyrightopgave).

Dopuch, N., R.W. Holthausen, R.W. Leftwich; Predicting Audit Qualifications with Financial and Market variables, in: The Accounting Review, July 1987 , pp. $431-454$.

Dorsman, A.B., A. Huizing (red.), Organisaties in her web van hun omgeving, 1989.

Douma, S.W., Op weg naar een economische organisatietheorie: agencytheorie, in: Maandblad voor Accountancy en Bedrijfshuishoudkunde, november 1987 , pp. $420-432$.

Europese Gemeenschappen, De Raad van de, Achtste Richtlijn van 10 april 1984.

Europese Gemeenschappen, De Raad van de, Richtlijn van de Raad betreffende een algemeen stelsel van erkenning van hoger-onderwijsdiploma"s waarmee beroepsopleidingen van tenminste drie jaar worden afgesloten (zg. 'Liberalisatierichtlijn'), tekst d.d. 16 december 1.988d.

Fédération des Experts Comptables Européens, (FEE), Training for the Profession, a Comparative Study, 1988.

Feenstra, D.W, De beste stumrlui...., oratie 20 mei 1988, Open Universiteit.

Fellingham, John C., D.P. Newman, Strategic Considerations in Auditing, in: The Accounting Review, October 1985, pp. 634-650.

Flint, D., Philosophy and Principles of Auditing, 1988. 
Flint, D., Acadenic research and accounting practice, in: The Accountant". Magazine, May 1988, pp. 29-30, 1988 b.

Francis, J.R., E.R. Wilson, Auditor Changes: A Joint Test of Theories Relating to Agency Costs and Auditor Differentiation, in: The Accounting Review, October 1988, pp. 663-682.

Frielink, A.B., De openbare accountant: vertrouwensman in en van het maatschappelijk werkeer, in: De Accountant, februari 1976, pp. 320-321.

Frielink, A.B., Een accountant is ook maar een mens, in: Intermediair, 1977, pp. 194-204.

Frielink, A.B., De accountantsfunctie, in: Maandblad voor Accountancy en Bedrijfshuishoudkunde, juli/augustus 1980, pp. 278-283.

Frielink, A.B., Het "axiomatisch voorbehoud" en de verklaring van oordeelonthouding, in: De Accountant, juli/augustus 1980, pp. 717-721, 1980 b.

Frielink, A.B., De GBR verklaard, 1984.

Frielink, A.B., Enkele opmerkingen aangaande accountantsverklaringen, in: Maatschappelijke Berichtgeving (afscheidsbundel J.W. Schoonderbeek; red. J. Klaassen et al.), 1986, pp. 255-264.

Gaffikin, MJ.R., Legacy of the Golden Age: Recent Developments in the Methodology of Accounting, in: Abacus, Vol. 24, No. 1, 1988, pp. 1635 .

Gedrags- en Beroepsregels Registeraccountants (GBR), NIvRA, 1988.

Geest, L. van der, Moderne scholastiek, in: ESB 5 aprill 1989.

Greene, G.E., The practitioner and the professor - a working partnership, in: Journal of Accountancy, February 1984, pp. 102, 104.

Groeneveld, G.L., Grandeur en zwakte van een systeem, in: Maandblad yoor Accountancy en Bedrijeshuishoudkunde, mei 1980, pp. 191-197.

Groeneveld, J.G., Ethiek: theorie en praktijk, aantekeningen bij de VERANajearsconferentie 1988, (3 delen), in: De Accountant, maart, april en mei 1989.

Guy, D.M. C.W. Alderman, Auditing, 1987. 
Gwilliam, D.R., A Survey of Auditing Research. 1987.

Gwilliam, D.R. The Auditor, Third Parties and Contributory Negligence, in: Accounting and Business Research, Vol. 18, No. 69, 1987b, pp. 2535.

Gwilliam, D.R., Apportionment in Actions Against Auditors, in: Abacus. Vol. 24, No. 1, 1988, pp. 37-54.

Haskins, M.E., D.D. Williams, The Association between Client Factors and Audit Fees: a Comparison by Country and by Firm, in: Accounting and Business Research, Vol. 18, No. 70, 1988, pp. 183-190.

Heer, H.J. de, J.A. van Manen, Enkele aspecten van de accountantscontrole bij multinationale ondernemingen, in: Maandblad woor Accountancy en Bedrijfshuishoudkunde, december 1988, pp. 641-659.

Hegarty, J., Recent developments with respect to professional ethics for accountants in Europe, paper voor Nivra Najaarsconferenties 1988.

Hofstede, G., Commentaar op Van de Poel: Berichtgeving en gedragswetenschappen, in: Keizer en Soeters, 1987, pp. 158-160.

Hogeweg, G.P.J., De ontwikkeling der Controleleer, openbare les, 13 December 1929 , Universiteit van Amsterdam.

Houghton, K.A., P. Robinson, Experimental Research in Auditing: Field vs. Laboratory Settings, in: Accounting and Business Research, Vol. 18, No. 69,1987, pp. $37-41$.

Van den Hout, A., Geestelijke Gezondheidkunde, oratie 28 oktober 1988, Rijksuniversiteit Limburg.

Hulsentop, L.A. van, Subjectieve aspecten van de accountantscontrole, oratie Katholieke Hogeschool Tilburg, 1976.

ICAEW (Institute of Chartered Accountants in England \& Wales), Research Plan en A Framework for Auditing Research, 1989.

Jensen, M.C., W.H. Meckling, Theory of the firm: Managerial Behavior, Agency Costs and Ownership Structure, in: Journal of Financial Economics 3, 1976, pp. 305-360.

Jensen, M.C., Organization Theory and Methodology, in: The Accounting Review, April 1983, pp. 319-339. 
Johnson, P.E., K. Jamal, R.G. Berryman, Audit Judgment Research, in: Accounting. Organizations and Society, Vol. 14, Nos. $1 / 2,1989, \mathrm{pp} .83-$ 99.

Jong, J. de, Kruidnagel in: De Accountant, oktober 1975, p. 71.

Kabela, M. Psychiatrisch onderzoek naar arbeidsongeschiktheid in het kader van de sociale verzekering, in: Het Medisch Jaar, 1988, pp. 251259.

Kalkman, S., De accountant van morgen, in: Het Financieele Dagblad, 2 mei 1989 ; p. 15.

Keizer, P.K., J. Soeters (red.), Economie, sociologie en psychologie: visies op integratie, 1987.

Klant, Over Limpergs methodologie, in: Maandblad voor Accountancy en Bedrijfshuishoudkunde, mei 1980 , pp. 187-190.

Kleerekoper, S., Inleiding in controle en accountantscontrole, in: Handboek Accountancy, deel I, 1971, pp. 1001-1029.

Klersey, G.F., Th.J. Mock, Verbal Protocol Research in Auditing, in: Accounting Organizations and Society, Vol. 14, Nos. 1/2, 1989, pp. $133-151$.

Knottnerus, J A., Dialectiek van het onderzoek in de huisartsgeneeskunde, oratie 29 september 1988, Rijksuniversiteit Limburg.

Koerselman, G.F., Bespreking van M. Kabela 'Psychiatrisch oordeel beoordeeld. De psychiatrische beoordeling van arbeidsongeschiktheid. 1988', in: Maandblad Geesteliike Volksgezondheid, 1989 nr. 1, pp. 77-78.

Krom, J.P.J., Audit Related Services, in: De Accountant, december 1988, pp. $171-174$.

Lange, $H$. de, De betekenis van EDP-Auditing voor de functie van de externe accountant, oratie 20 januari 1989 . Vrije Universiteit.

Langendijk, H.P.A.J., De onafhankelijkheid van de externe accountant vanuit een "agency theory" perspectief, in: Dorsman en Huizing, 1989, pp. 45-59.

Leerboek Accountantscontrole (LAC), eindred. A.B. Frielink, HJ. de Heer, deel I, 1985. 
Levinthal, D.A., M. Fichman, Dynamics of Interorganizational Attachnuents: Auditor-Client Relationships, in: Administrative Science Ouaterly, September 1988 , pp. $345-369$.

Limperg jr., Th., De functie van de accountant en de leer van het gewekte vertrouwen, 1932/1933 (opgenomen in: Vijfig jaar MAB deel 2, 1974 , pp. 222-251).

Limperg jr., Th., Een Nederlandse accountantsverklaring in de Engelse pers, in: Maandblad voor Accountancy en Bedrifshuishoudkunde, december 1934 (pp. 173-175) en januari 1935 (pp. 1-3).

Limperg jr., Th., De uitvoerige accountantsverklaring, in: Maandblad voor Accountancy en Bedrijfshuishoudkunde, april 1939 , pp. $50-52$.

Limperg jr, Th., Naschrift (bij Belle, 1940), in: Maandblad voor Accountancy en Bedrijfshuishoudkunde, januari 1940, pp. 4-9.

Limperg jr, Th., Bedrijfseconomie, Verzameld werk, deel I, Algemene inleiding tot de bedrijfshuishoudkunde en leer van de waarde, 1964.

Limperg jr., Th., Bedrijfseconomie, Verzameld werk, deell VI, Leer van de accountantscontrole en van de winstbepaling, 1965.

Limperg/Groeneveld, Leer van de Accountantscontrole, (uit: deel VI van het verzameld werk Bedrijfseconomie van Th. Limperg jr., bijgewerkt door G.L. Groeneveld), 1976.

Limperg Instituut, The social responsibility of the auditor, 1985.

Limperg Instituut, Opvattingen over accountants, 1987.

MacArthur, J.B., Some Implications of Auditor and Client Lobbying Activities: A Comparative Analysis, in: Accounting and Business Research, Vol. 19, No. 73, 1988, pp. 56-64.

Maijoor, S., The economic theory of accounting regulation: an application to dutch accounting legislation. Working Paper 89-005, Faculteit der Economische Wetenschappen, Rijksuniversiteit Limburg, 1989.

Mautz, R.K., H.A. Sharaf, The Philosophy of Auditing, 1961.

McKinnon, J., Reliability and Validity in Field Research: Some Strategies and Tactics, in: Accounting. Auditing and Accountability, 1988/1, pp. 34-54. 
Metzemaekers, L.A.V.M. Een eeuw in balans, 1983.

Mey, A., De noodzaak van een normatieve theorie der accountants-controle als leidraad voor de beroepsuitoefening, (prae-advies, toelichting en debat), 1936.

Modderaar, J., Enkele opmerkingen over de ontwikkeling van het accountantswezen in Engeland en in Nederland, in: Van Boekhouden tot Bedriffsleer "Opstellen aangeboden aan Prof. Dr. J.G.Ch. Volmer, 1934, pp. 212-230.

Moizer, P., S. Turley, Changes in the UK market for audit services: 19721982, in: Journal of Business Funance \& Accounting, Spring 1989 pp. $41-53$.

Morris, M.H., W.D. Nichols, Consistency Exceptions: Materiality Judgments and Audit Firm Structure, in: The Accounting Review, April 1988, pp. 237-254.

Morris, R.D., Signalling, Agency Theory and Accounting Policy Choice, in: Accounting and Business Research, Vol, 18, No. 69, 1987, pp. 47-56.

NIVA (Nederlandsch Instituut Van Accountants), De Accountant, 1938 (o.a. bevattend debatten over de opleiding tot accountant).

NIvRA, Using Expert Systems, Documentatie International Conference, 2628 September 1988 .

NIvRA, Studiegids 89/90, 1989.

Nordemann, H.H.J., De Algemene Controle: schets van een ontwikkeling, in: Hoor en Wederhoor, Artikelen aangeboden aan prof. dr. A.B. Frielink, 1984, pp. 99-116.

Nordemann, H.H.J., Address by the president of FEE to the Board of LASC, 14 april 1989 (verkrijgbaar bij FEE).

Oonincx, J.A.M., R.A.M. Pruijm, Externe controle bij systemen voor automatische informatieverzorging, 1987.

Ophof, H.P.J, Den accountant getrouwe, in: De Accountant, maart 1988, pp. 296-298.

Perspectives on Education: Capabilities for Success in the Accounting Profession, Chairmen Big Eight Firms, Aprill 1989. 
Pinkhof, I., Het subjectieve element bij de bepaling der werantwoordelijkheid van den accountant, in: Maandblad voor Accountancy en Bedrijsshuishoudkunde, december 1933, pp. 218-220.

Poel, J.H.R. van de, Als de tekenen bedriegen...., oratie 4 maart 1988, Rijksuniversiteir Limburg.

Poel, J.H.R. van de, E.H.J. Vaassen, Audit Judgment research, Accountantscontrole en menselijke beslissingsprocessen, Researchmemorandurn 88033, Faculteit der Economische Wetenschappen, Rijksuniversiteit Limburg, 1988.

Poel, J.H.R. van de, Buy-out en accountability, in: Buy-out en accountant, NIvRA Geschrift 47,1989 , pp. $33-52$.

Poel, J.H.R van de, A. Schilder, Auditor Independence: A Dutch Experiment, Research Memorandum 89-013, Faculteit der Economische Wetenschappen, Rijksuniversiteit Limburg, 1989.

Radebaugh, L.H., Book Review inzake: R.K. Ashton, The Use and Extent of Replacement Value Accounting in the Netherlands, in: The Accounting Review, January 1983, pp. 172-174.

Ricchiute, D.N., Auditing, 1988.

Roscam Abbing, A.D.H., Perspectieven voor Spiritualiteit: De Klinische Pastorale Vorming, 21 p., 1988, (verkrijgbaar bij Psychiatrisch Ziekenhuis Denneoord, Zuidlaren).

Schilder, Aleid, Hulpeloos maar schuldig, 1987.

Schilder, A., Inleiding op: De accountant in de 90-er jaren, in: Symposiumbundel 11 september 1987, Centrum voor PDO, Vrije Universiteit.

Schilder, A., Kernbegrippen van accountantsethiek, Research Memorandum 89-008, Faculteit der Economische Wetenschappen, Rijksuniversiteit Limburg, 1989.

Schoonderbeek, J.W., Recht op de openbare accountant af, in: Hoor en Wederhoor, Artikelen aangeboden aan prof, dr. A.B. Frielink, 1984, pp. $175-180$.

Schoonderbeek, J.W., Accountantsverantwoording, Afscheidscollege 10 november 1986 , Vrije Universiteit. 
Shanteau, J.s Cognitive Hewristics and Biases in Behavioral Auditing: Review. Comments and Observations, in: Accounting. Organizations and Sociery: Vol. 14, Nos. 1/2, 1989, pp. 165-177.

Shanteau, J., IM. Peters, The 3C s of Expent Audit Judgment: Creativity, Confidence and Communication; Paper prepared for the February, 1989 USC Audit Judgment Symposium.

Soeters, J, H. Schreuder, Werkprestaties in accountantskantoren, in: Maandblad voor Accountancy en Bedrijfshishoudkunde, december 1986, pp. $467-486$

Steinbart P.J., The Construction of a Rule-Based Expert System as a Method for Studying Materiality Judgments, in: The Accounting Review, January $1987, \mathrm{pp} .97-116$.

Sternheim, A. Leerboek der accountancy, deel IIIA, De Accountantscontrole (Algemeene beginselen), 1924.

Stevers, Th. A., Van spelers en schollasten, afscheidscollege 31 maart 1989 Katholieke Universiteit Brabant.

Stewart, I.C., The explication of the true and fair view doctrine: a comment, in: Journal of Business Finance \& Accounting, Spring 1985, pp. 115-123 (met aansluitend een reactie van $B_{n} A$. Rutherford).

Stokkom, B. van, De filosofische overwegingen van Popper, Checkland en Burrell, in: NIVE Nieuws, oktober 1988, pp. 7, 9.

Straater, H.C. van, De Leer van Limperg, geloof of wetenschap? In: Herimeringen aan Limperg, 1979, pp. 89-90.

Studierapport 'De reikwijdte van de accountantsverklaring', NIvRA 1978.

Taylor, D.H., G.W. Glezen, Auditing, 1988.

The History of the Institute of Chartered Accountants in England \& Wales \& its founder bodies, 1966.

Treadway, Report of the National Commission on Fraudulent Financial Reporting, October 1987.

Trompert, K., Een Amsterdamse lente - 100 jaar Limperg 1879-1979, 1988. 
Ven, J.A., van der, Zin en onzin van het lijden: Proeve van wen ontwikkelingsmodel, in: Rond godsdienst en psychoanalyse, (Essays voor dr. Anold Uleyn, red. J.A. van Belzen en J.M. van der Lans), 1986, pp. $188-207$.

Vries, J. de, Geschiedenis der Accountancy in Nederland, 1985.

Watts, R.L., J.L. Zimmerman, Agency problems, auditing, and the theory of the firm: some evidence, in: The Joumal of Law and Economics, October 1983 , pp. $613-633$.

White, C.E., The Maturing of Expert Systems in Accounting and Auditing, in. NIvRA, 1988.

Williams, D.D., The potential determinants of auditor change, in: Journal of Business Finance A Accounting, Summer 1988, pp. 243-261.

Williams, D.D., M.W. Dirsmith, The effects of audit technology on auditor efficiency: auditing and the timeliness of client earnings announcements, in: Accounting, Organizations and Society, Vol. 13, No. 5, 1988, pp. 487-508.

Wilschut, K.P.G., Het primaire object van de accountantscontrole, in: De Accountant, februari 1987 , pp. 244-250.

Wilschut, K.P.G., Onbegrip rondom axiomatisch voorbehoud, verantwoording en verwachtingskloof, in: De Accountant, november 1987, pp. 106108 .

Wilschut, K.P.G., Vertrouwensleer en verwachtingskloof, in: De Accountant, februari 1988 , pp. 263-266.

Wolnizer, Auditing as independent authentication, 1987.

Woolf, E., Auditing, 1988 .

Wright, A., The impact of prior working papers on auditor evidential planning judgments, in: Accounting, Organizations and Society, Vol. 13, No. 6,1988, pp. $595-605$.

Zacchea, NM., The Multinational Auditor: Overcoming Cultural Differences to Apply Audit Standards, in: Intemal Auditor, October 1988. 